\title{
$\Delta$ FosB Induction in Striatal Medium Spiny Neuron Subtypes in Response to Chronic Pharmacological, Emotional, and Optogenetic Stimuli
}

\author{
Mary Kay Lobo, ${ }^{1}$ Samir Zaman, ${ }^{2}$ Diane M. Damez-Werno, ${ }^{2}$ Ja Wook Koo, ${ }^{2}$ Rosemary C. Bagot,${ }^{2}$ Jennifer A. DiNieri, ${ }^{2,3}$ \\ Alexandria Nugent, ${ }^{4}$ Eric Finkel, ${ }^{1}$ Dipesh Chaudhury, ${ }^{2}$ Ramesh Chandra, ${ }^{1}$ Efrain Riberio, ${ }^{2}$ Jacqui Rabkin, ${ }^{2}$ \\ Ezekiell Mouzon, ${ }^{2}$ Roger Cachope, ${ }^{1}$ Joseph F. Cheer, ${ }^{1}$ Ming-Hu Han, ${ }^{2}$ David M. Dietz, ${ }^{5}$ David W. Self, ${ }^{4}$ Yasmin L. Hurd, ${ }^{2,3}$ \\ Vincent Vialou, ${ }^{6}$ and Eric J. Nestler ${ }^{2,3}$ \\ ${ }^{1}$ Department of Anatomy and Neurobiology, University of Maryland School of Medicine, Baltimore, Maryland 21201, ${ }^{2}$ Fishberg Department of \\ Neuroscience and Friedman Brain Institute, Icahn School of Medicine at Mount Sinai, New York, New York 10029, ${ }^{3}$ Departments of Psychiatry and of \\ Pharmacology and Systems Therapeutics, Icahn School of Medicine at Mount Sinai, New York, New York 10029, ${ }^{4}$ Department of Psychiatry, University \\ of Texas Southwestern Medical Center, Dallas, Texas 75390, 5 Department of Pharmacology and Toxicology and the Research Institute on Addictions, State \\ University of New York at Buffalo, New York, New York 14214, and 'Institut National de la Santé et de la Recherche Médicale, U952, Centre National de la \\ Recherche Scientifique, Unité Mixte de Recherche 7224, UPMC, Paris, 75005, France
}

The transcription factor, $\Delta \mathrm{FosB}$, is robustly and persistently induced in striatum by several chronic stimuli, such as drugs of abuse, antipsychotic drugs, natural rewards, and stress. However, very few studies have examined the degree of $\Delta$ FosB induction in the two striatal medium spiny neuron (MSN) subtypes. We make use of fluorescent reporter BAC transgenic mice to evaluate induction of $\Delta$ FosB in dopamine receptor 1 (D1) enriched and dopamine receptor 2 (D2) enriched MSNs in ventral striatum, nucleus accumbens (NAc) shell and core, and in dorsal striatum (dStr) after chronic exposure to several drugs of abuse including cocaine, ethanol, $\Delta(9)$ tetrahydrocannabinol, and opiates; the antipsychotic drug, haloperidol; juvenile enrichment; sucrose drinking; calorie restriction; the serotonin selective reuptake inhibitor antidepressant, fluoxetine; and social defeat stress. Our findings demonstrate that chronic exposure to many stimuli induces $\Delta$ FosB in an MSN-subtype selective pattern across all three striatal regions. To explore the circuit-mediated induction of $\Delta$ FosB in striatum, we use optogenetics to enhance activity in limbic brain regions that send synaptic inputs to NAc; these regions include the ventral tegmental area and several glutamatergic afferent regions: medial prefrontal cortex, amygdala, and ventral hippocampus. These optogenetic conditions lead to highly distinct patterns of $\Delta$ FosB induction in MSN subtypes in NAc core and shell. Together, these findings establish selective patterns of $\Delta$ FosB induction in striatal MSN subtypes in response to chronic stimuli and provide novel insight into the circuit-level mechanisms of $\Delta$ FosB induction in striatum.

\section{Introduction}

Chronic stimuli, including drugs of abuse, antipsychotic drugs, stress, and natural rewards, cause the stable accumulation of $\Delta$ FosB, a truncated product of the FosB gene, in striatum (e.g., Hope et al., 1994; Hiroi and Graybiel, 1996; Hiroi et al., 1997; Moratalla et al., 1996; Perrotti et al., 2004, 2008; Muller and Unterwald, 2005; McDaid et al., 2006; Teegarden and Bale, 2007; Wallace et al., 2008; Solinas et al., 2009; Vialou et al., 2010, 2011; Kaplan et al., 2011). This accumulation leads to the bidirectional

Received May 3, 2013; revised Sept. 27, 2013; accepted Oct. 3, 2013.

Author contributions: M.K.L., J.F.C., M.-H.H., D.M.D., D.W.S., Y.L.H., V.V., and E.J.N. designed research; M.K.L., S.Z., D.M.D.-W., J.W.K., R.C.B., J.A.D., A.N., E.F., D.C., R. Chandra, E.R., J.R., E.M., R. Cachope, and V.V. performed research; M.K.L., S.Z., and D.C. analyzed data; M.K.L. and E.J.N. wrote the paper.

The authors declare no competing financial interests.

Correspondence should be addressed to Dr. Eric J. Nestler, Fishberg Department of Neuroscience and Friedman

Brain Institute, Icahn School of Medicine at Mount Sinai, One Gustave L. Levy Place, Box 1065, New York, NY 10029. E-mail: eric.nestler@mssm.edu.

DOI:10.1523/JNEUROSCI.1875-13.2013

Copyright $(\odot 2013$ the authors $\quad 0270-6474 / 13 / 3318381-15 \$ 15.00 / 0$ regulation of many genes by $\Delta \mathrm{FosB}$ in this brain region (McClung and Nestler, 2003; Renthal et al., 2008, 2009; Vialou et al., 2010; Robison and Nestler, 2011). The striatum is composed mainly ( $\sim 95 \%)$ of GABAergic projection medium spiny neurons (MSNs), which are segregated into two subtypes based on their enrichment of many genes, including dopamine receptor 1 (D1) or dopamine receptor 2 (D2) (Gerfen, 1992; Graybiel, 2000; Lobo et al., 2006; Heiman et al., 2008) and by their differential outputs to distinct subcortical structures (Albin et al., 1989; Gerfen, 1992; Kalivas et al., 1993; Graybiel, 2000; Nicola, 2007; Smith et al., 2013). Recently, there has been an abundance of reports demonstrating distinct molecular and functional roles of these MSN subtypes in ventral striatum (nucleus accumbens [NAc]) and dorsal striatum (dStr) in mediating motivational and motor behaviors (Lobo and Nestler, 2011; Gittis and Kreitzer, 2012).

Previous studies have demonstrated that $\Delta \mathrm{FosB}$ is induced primarily in D1-MSNs by chronic treatment with cocaine or chronic wheel running, a form of natural reward (Moratalla et al., 1996; Werme et al., 2002; Lee et al., 2006), whereas chronic re- 
straint stress induces $\Delta$ FosB in both MSN subtypes (Perrotti et al., 2004). Further, compelling evidence from cell type-specific transgenic lines or viral-mediated gene transfer demonstrates that $\triangle$ FosB induction in D1-MSNs increases behavioral and structural plasticity to cocaine, behavioral responses to morphine, wheel running, food reward, and resilience to chronic social defeat stress, whereas $\triangle$ FosB induction in D2-MSNs negatively regulates behavioral responses to wheel running (Kelz et al., 1999; Werme et al., 2002; Colby et al., 2003; Olausson et al., 2006; Zachariou et al., 2006; Vialou et al., 2010; Grueter et al., 2013; Robison et al., 2013).

Given the crucial role for $\Delta \mathrm{FosB}$ in regulating these chronic motivational stimuli, with distinct effects in D1-MSNs versus D2-MSNs, we perform here a comprehensive study on the patterns of $\Delta$ FosB induction in MSN subtypes by several chronic stimuli, including chronic exposure to drugs of abuse, chronic treatment with an antipsychotic drug, chronic exposure to altered environmental and appetitive stimuli, chronic social defeat stress, and chronic treatment with an antidepressant. To understand the circuit mechanisms controlling $\Delta$ FosB induction in striatum by several afferent limbic brain regions, we use optogenetic technologies to repeatedly activate cell bodies in dopaminergic or glutamatergic afferent brain regions and examine the resulting $\triangle$ FosB induction in MSN subtypes. Our results provide novel insight into the induction of $\Delta$ FosB in striatal D1-MSNs and D2-MSNs by chronic stimuli and, for the first time, demonstrate the circuit-mediated induction of $\Delta$ FosB in striatum and within selective MSN subtypes.

\section{Materials and Methods}

Animals. D1-GFP or D2-GFP hemizygote mice (Gong et al., 2003) on a C57BL/6 background were maintained on a $12 \mathrm{~h}$ light dark cycle with ad libitum food and water. All studies were conducted in accordance with the guidelines set up by the Institutional Animal Care and Use Committees at the University of Maryland School of Medicine and Icahn School of Medicine at Mount Sinai. Male mice (age 8 weeks) were used for all experiments. All mice were perfused, and brains were collected during the afternoon of the light cycle. Hemizygote D1-GFP and D2-GFP mice on a $\mathrm{C} 57 \mathrm{BL} / 6$ or $\mathrm{FVB} / \mathrm{N}$ background have been shown to be equivalent to wild-type mice with respect to behavior, physiology of D1-MSNs and D2-MSNs, and development of the MSNs (Lobo et al., 2006; Chan et al., 2012; Nelson et al., 2012). Moreover, the overall patterns of $\Delta$ FosB induction seen in this study are comparable with those seen in wild-type animals with non-cell type-selective tools (e.g., Perrotti et al., 2004, 2008).

Cocaine treatment. D1-GFP ( $n=4$ per treatment $)$ and D2-GFP $(n=4$ per treatment) mice received 7 daily intraperitoneal injections of cocaine $(20 \mathrm{mg} / \mathrm{kg})$ or $0.9 \%$ saline in the home cage. For 1 or $3 \mathrm{~d}$ cocaine $(20$ $\mathrm{mg} / \mathrm{kg}$ ) injections, mice received 6 or $4 \mathrm{~d}$ of $0.9 \%$ saline injections followed by 1 or $3 \mathrm{~d}$ of cocaine injections, respectively. All mice were perfused $24 \mathrm{~h}$ after the last injection. This dose of cocaine was selected based on previous studies (e.g., Maze et al., 2010).

Haloperidol treatment. D1-GFP ( $n=3$ or 4 per treatment $)$ and D2GFP $(n=4$ per treatment $)$ mice received haloperidol $(2 \mathrm{mg} / \mathrm{kg})$ in the drinking water, $\mathrm{pH} 6.0$ (Narayan et al., 2007), or regular drinking water, $\mathrm{pH} 6.0$, for 3 weeks $(21 \mathrm{~d})$. Mice were perfused on day 22.

Morphine treatment. D2-GFP mice ( $n=4$ or 5 per treatment) were briefly anesthetized with isoflurane and received subcutaneous implants of morphine $(25 \mathrm{mg})$ or sham pellets on day 1 and day 3 as previously described (Mazei-Robison et al., 2011). Mice were perfused on day 5.

Ethanol treatment. D2-GFP mice ( $n=4$ or 5 per treatment) were exposed to $10 \%$ ethanol (EtOH), a dose that C57BL/6 have been shown to drink (Yoneyama et al., 2008). Mice were given a two bottle choice test for $10 \% \mathrm{EtOH}$ (bottle A) and water (bottle B), whereas D2-GFP controls received water in both bottles (bottle A and $\mathrm{B}$ ) for $10 \mathrm{~d}$. All mice receiving $\mathrm{EtOH}$ bottles exhibited a preference for $\mathrm{EtOH}$ as calculated by $(100 \times$ bottle A volume/[bottle A volume + bottle B volume]). Mice that received the $10 \% \mathrm{EtOH}$ bottle consumed significantly more $\mathrm{EtOH}$ compared with water, whereas mice receiving water in both bottles demonstrated no difference in liquid consumption. On the evening of day 10 , all mice were given normal drinking water and were perfused on day 11 .

$\Delta$ (9)-tetrahydrocannabinol ( $\Delta(9)-T H C)$ treatment. D2-GFP $(n=3$ per treatment) mice received intraperitoneal injections of $\Delta(9)$-THC (10 $\mathrm{mg} / \mathrm{kg})$ or vehicle $(0.9 \%$ saline with $0.3 \%$ Tween $)$ twice a day for $7 \mathrm{~d}$ (Perrotti et al., 2008). Mice were perfused $24 \mathrm{~h}$ after the last injection.

Cocaine self-administration. D2-GFP mice ( $n=4$ or 5 per treatment) were initially trained to lever press for $20 \mathrm{mg}$ sucrose pellets on a fixed ratio 1 (FR1) reinforcement schedule until an acquisition criterion of 30 sucrose pellets consumed for 3 consecutive test days was reached according to standard procedures (Larson et al., 2010). Mice that learned to lever press were surgically implanted with an intravenous jugular catheter to allow for subsequent cocaine intravenous administration. One week after surgery, mice were introduced to the self-administration paradigm during $2 \mathrm{~h}$ daily sessions on an FR1 schedule of reinforcement. The self-administration equipment (Med Associates) was programmed such that a response on the active lever resulted in the delivery (over $2.5 \mathrm{~s}$ ) of cocaine $(0.5 \mathrm{mg} / \mathrm{kg} /$ infusion per correct lever press), whereas a response on the inactive lever had no programmed consequence. Mice self-administered cocaine on an FR 1 schedule in daily $2 \mathrm{~h}$ sessions, $5 \mathrm{~d}$ per week, for 3 weeks. D2-GFP mice receiving $0.9 \%$ saline injections over the equivalent time period were used as controls. Mice were perfused $24 \mathrm{~h}$ after the last cocaine or saline administration.

Heroin self-administration. Before heroin self-administration, D2-GFP mice ( $n=4$ per treatment) were trained to lever press for chocolate pellets (BioServ, Dustless Precision Pellets) in seven $1 \mathrm{~h}$ daily sessions. Mice that learned to lever press were surgically implanted with an intravenous jugular catheter to allow for subsequent heroin intravenous administration. One week after surgery, mice were introduced to the self-administration paradigm during $3 \mathrm{~h}$ daily sessions on a FR 1 schedule of reinforcement according to standard procedures (Navarro et al., 2001). The self-administration equipment (Med Associates) was programmed such that a response on the active lever resulted in the delivery (over $5 \mathrm{~s}$ ) of heroin $(30 \mu \mathrm{g} / \mathrm{kg} /$ injection; NIDA Drug Supply Program), whereas a response on the inactive lever had no programmed consequence. Animals were given access to the heroin self-administered procedure for $14 \mathrm{~d}$. D2-GFP mice receiving $0.9 \%$ saline injections over the equivalent time period were used as controls. Mice were perfused $24 \mathrm{~h}$ after the last heroin or saline administration.

Juvenile environmental enrichment. D2-GFP ( $n=4$ per group) mice were weaned into an enriched environment or normal housing conditions at postnatal day 21 (P21) using a paradigm adapted from rats (Green et al., 2010). The enriched environment consisted of a larger hamster cage with enrich-o-cob bedding (Andersons Laboratory bedding) filled with enrichment devices that included mouse tunnels, dome and wheels, crawl balls, huts (Bio Serv), and other toys. Mice remained in the housing conditions for 4 weeks until P50 and were then perfused.

Sucrose treatment. D2-GFP mice ( $n=4$ or 5 per treatment) were given a two bottle choice test for $10 \%$ sucrose similar to a previous study (Wallace et al., 2008). Mice were given 10\% sucrose (bottle A) and water (bottle B), whereas D2-GFP controls received water in both bottles for $10 \mathrm{~d}$. All mice receiving sucrose bottles exhibited a preference for sucrose as calculated by $(100 \times$ bottle A volume/bottle A volume + bottle B volume). Mice that received the $10 \%$ sucrose bottle consumed significantly more sucrose compared with water, whereas mice receiving water in both bottles demonstrated no difference in liquid consumption. On the evening of day 10, all mice were given normal drinking water and were perfused on day 11

Calorie restriction. D2-GFP mice ( $n=4$ per genotype) went through a calorie restriction protocol, in which they received $60 \%$ of ad libitum calories daily (Vialou et al., 2011) for $10 \mathrm{~d}$. D2-GFP control mice received full access to chow. On the evening of day 10 , all mice received full access to chow and were perfused on day 11 .

Social defeat stress. D2-GFP mice ( $n=4$ or 5 per group) underwent $10 \mathrm{~d}$ of social defeat stress as described previously (Berton et al., 2006; 
Krishnan et al., 2007). Mice were exposed to aggressive CD1 retired breeders for $5 \mathrm{~min}$ in a large hamster cage. Mice were then housed for $24 \mathrm{~h}$ in the same cage on the other side of a perforated divider to maintain sensory contact. The next day mice were exposed to a new CD1 mouse under the same conditions and housing. This was repeated for $10 \mathrm{~d}$ with a new $\mathrm{CD} 1$ each day. Control mice were housed under similar conditions without defeat stress. Mice were tested for social interaction on day 11. Mice were first tested for time spent interacting with a novel chamber in an open field box without another mouse present (no target) and then subsequently tested for time spent interacting with a novel CD1 mouse (target) that was contained behind the chamber (Berton et al., 2006; Krishnan et al., 2007). Mice were segregated into susceptible or resilient groups based on parameters previously described (Krishnan et al., 2007). This included overall time spent with the novel mouse and the interaction ratio: (time spent with target/time spent with no target) $\times 100$. This measure has been shown to reliably identify susceptible and resilient groups and is highly correlated with other behavioral differences (Krishnan et al., 2007). All mice were perfused $24 \mathrm{~h}$ after the social interaction test ( $48 \mathrm{~h}$ after the last social defeat episode).

Fluoxetine treatment. D2-GFP mice ( $n=3$ or 4 per group) received 14 daily intraperitoneal injections of fluoxetine $(20 \mathrm{mg} / \mathrm{kg})$ or vehicle $(0.9 \%$ saline with $10 \%$ cyclodextrin) (Berton et al., 2006). Mice were perfused $24 \mathrm{~h}$ after the last injection.

Stereotaxic surgery. D2-GFP mice were anesthetized with ketamine $(100 \mathrm{mg} / \mathrm{kg}) / x y l a z i n e(10 \mathrm{mg} / \mathrm{kg})$, placed in a small-animal stereotaxic instrument, and their skull surface was exposed. Thirty-three gauge syringe needles were used to unilaterally infuse $0.5-1 \mu \mathrm{l}$, at a rate of $0.1 \mu \mathrm{l}$ per minute, of virus bilaterally into the ventral tegmental area (VTA), medial prefrontal cortex (mPFC), amygdala, or ventral hippocampus (vHippo). AAV [adeno-associated virus]-hSyn-ChR2 [channelrhodopsin 2]-EYFP or AAV-hSyn-EYFP was infused into the VTA of D2-GFP mice ( $n=5$ per group) at stereotaxic coordinates (anterior-posterior, $-3.3 \mathrm{~mm}$; lateral-medial, $0.5 \mathrm{~mm}$; dorsal-ventral, $-4.4 \mathrm{~mm}, 0^{\circ}$ angle). This was followed by bilateral cannula (26-gauge), with a length of $3.9 \mathrm{~mm}$, implantation over the VTA (anterior-posterior, $-3.3 \mathrm{~mm}$; lateral-medial, $0.5 \mathrm{~mm}$; dorsal-ventral, $-3.7 \mathrm{~mm}$ ) (Koo et al., 2012; Chaudhury et al., 2013). AAV-CaMKII-ChR2-mCherry or AAV-CaMKII-mCherry were injected into the $\mathrm{mPFC}$ ( $n=4$ or 5 per group), amygdala ( $n=3$ or 4 per group), or vHippo ( $n=3$ or 4 per group) of D2-GFP mice followed by implantation of $105 \mu \mathrm{m}$ chronic implantable optic fibers (Sparta et al., 2011). Coordinates were as follows: $\mathrm{mPFC}$ (infralimbic was targeted, but we observed spillover of virus to prelimbic regions: anterior-posterior, $1.7 \mathrm{~mm}$; lateral-medial, $0.75 \mathrm{~mm}$; dorsal-ventral, $-2.5 \mathrm{~mm}, 15^{\circ}$ angle) and optic fiber (dorsal-ventral, $-2.1 \mathrm{~mm}$ ); amygdala (basolateral amygdala was targeted, but we observed spillover of virus into the central nucleus of the amygdala; anteriorposterior, $-1.6 \mathrm{~mm}$; lateral-medial, $3.1 \mathrm{~mm}$; dorsal-ventral, $-4.9 \mathrm{~mm}, 0^{\circ}$ angle) and optic fiber (dorsal-ventral, $-4.9 \mathrm{~mm}$ ); vHippo (ventral subiculum was targeted, but we observed spillover of virus into other regions of ventral hippocampus; anterior-posterior, $-3.9 \mathrm{~mm}$; lateral-medial, 3.0 $\mathrm{mm}$; dorsal-ventral, $-5.0 \mathrm{~mm}, 0^{\circ}$ angle) and optic fiber (dorsal-ventral, $-4.6 \mathrm{~mm}$ ).

Optogenetic conditions. For in vivo optical control of VTA neuronal firing, a $200 \mu \mathrm{m}$ core optic fiber patch cord was modified for attachment to the cannula. When the fiber was secured to the cannula, the tip of the fiber extended $\sim 0.5 \mathrm{~mm}$ beyond the cannula (Lobo et al., 2010; Chaudhury et al., 2013). For in vivo optical control of mPFC, amygdala, and vHippo neuronal firing, a $62.5 \mu \mathrm{m}$ split fiber patch cord was attached to the implantable head mount fibers (Sparta et al., 2011). Optic fibers were attached through an FC/PC adaptor to a $473 \mathrm{~nm}$ blue laser diode (Crystal Lasers, BCL-473-050-M), and light pulses were generated through a stimulator (Agilent, 33220A). For VTA, blue light $(473 \mathrm{~nm})$ phasic pulses, $20 \mathrm{~Hz}$ for $40 \mathrm{~ms}$ (Chaudhury et al., 2013), were delivered for 10 min a day over $5 \mathrm{~d}$. For mPFC, amygdala, and vHippo, blue light (473 $\mathrm{nm}$ ) pulses, $20 \mathrm{~Hz}$ for $30 \mathrm{~s}$, were delivered for $10 \mathrm{~min}$ a day for $5 \mathrm{~d}$. Light delivery occurred in the home cage, and all mice were perfused $24 \mathrm{~h}$ after the last light stimulation.

In vitro patch-clamp electrophysiology. Whole-cell recordings were obtained from VTA dopamine neurons or mPFC glutamatergic neurons in acute brain slices from mice injected with viruses noted above. Slice recordings were performed on mice with no in vivo stimulation, but with $1 \mathrm{~d}$ of slice stimulation ( $1 \mathrm{~d}$ ) or $4 \mathrm{~d}$ of in vivo stimulation and $1 \mathrm{~d}$ of slice stimulation $(5 \mathrm{~d})$. To minimize stress and to obtain healthy slices, mice were anesthetized immediately after being brought to the electrophysiology area and perfused for 40-60 s with ice-cold aCSF, which contained $128 \mathrm{~mm} \mathrm{NaCl}, 3 \mathrm{~mm} \mathrm{KCl}, 1.25 \mathrm{~mm} \mathrm{NaH}_{2} \mathrm{PO}_{4}, 10 \mathrm{~mm}$ D-glucose, $24 \mathrm{~mm}$ $\mathrm{NaHCO}_{3}, 2 \mathrm{~mm} \mathrm{CaCl}_{2}$, and $2 \mathrm{~mm} \mathrm{MgCl}$ (oxygenated with $95 \% \mathrm{O}_{2}$ and $5 \% \mathrm{CO}_{2}, \mathrm{pH} 7.4,295-305 \mathrm{mOsm}$ ). Acute brain slices containing mPFC or VTA were cut using a microslicer (Ted Pella) in cold sucrose-aCSF, which was derived by fully replacing $\mathrm{NaCl}$ with $254 \mathrm{~mm}$ sucrose and saturated by $95 \% \mathrm{O}_{2}$ and $5 \% \mathrm{CO}_{2}$. Slices were maintained in a holding chamber with aCSF for $1 \mathrm{~h}$ at $37^{\circ} \mathrm{C}$. Patch pipettes (3-5 M $\Omega$ ), for wholecell current, were filled with internal solution containing the following: $115 \mathrm{~mm}$ potassium gluconate, $20 \mathrm{~mm} \mathrm{KCl}, 1.5 \mathrm{~mm} \mathrm{MgCl}_{2}, 10 \mathrm{~mm}$ phosphocreatine, $10 \mathrm{~mm}$ HEPES, $2 \mathrm{~mm}$ magnesium ATP, and $0.5 \mathrm{~mm}$ GTP (pH 7.2, $285 \mathrm{mOsm})$. Whole-cell recordings were performed using aCSF at $34^{\circ} \mathrm{C}$ (flow rate $=2.5 \mathrm{ml} / \mathrm{min}$ ). Blue light trains $(20 \mathrm{~Hz}$ for $\mathrm{mPFC}$ or phasic $20 \mathrm{~Hz}, 40 \mathrm{~ms}$ for VTA) were generated by a stimulator connected via a FC/PC adaptor to a $473 \mathrm{~nm}$ blue laser diode (OEM) and delivered to mPFC and VTA slices via a $200 \mu \mathrm{m}$ optical fiber. Current-clamp experiments were performed using the Multiclamp 700B amplifier, and data acquisition was performed in pClamp 10 (Molecular Devices). Series resistance was monitored during the experiments, and membrane currents and voltages were filtered at $3 \mathrm{kHz}$ (Bessel filter).

Immunohistochemistry. Mice were anesthetized with chloral hydrate and perfused with $0.1 \mathrm{~m}$ PBS followed by $4 \%$ paraformaldehyde in PBS. Brains were postfixed in $4 \%$ paraformaldehyde overnight and then cyropreserved in $30 \%$ sucrose. Brains were sectioned on a cryostat (Leica) at $35 \mu \mathrm{m}$ into PBS with $0.1 \%$ sodium azide. For immunohistochemistry, sections were blocked in 3\% normal donkey serum with $0.01 \%$ Triton-X in PBS for $1 \mathrm{~h}$ on the shaker at room temperature. Sections were then incubated in primary antibodies in block overnight on the shaker at room temperature. Antibodies used were the following: rabbit anti-FosB (1:2000, catalog \#sc-48, Santa Cruz Biotechnology), mouse anti-NeuN (1:1000, catalog \#MAB377, Millipore), chicken anti-GFP (1:5000, cata$\log \# 10-20$, Aves), and rabbit anti-CREB (cAMP response element binding protein; 1:1000, catalog \#06-863, Millipore). The next day, sections were rinsed in PBS followed by a $1 \mathrm{~h}$ incubation in secondary antibodies: donkey anti-rabbit Cy3, donkey anti-mouse Cy5, and donkey antichicken DyLight- 488 or Alexa-488 (Jackson ImmunoResearch Laboratories). For mCherry and tyrosine hydroxylase immunohistochemistry, experiments were performed as previously described (Lobo et al., 2010; Mazei-Robison et al., 2011). Sections were rinsed in PBS, mounted onto slides, and coverslipped.

Imaging and cell counting. Immunofluorescence was imaged on a Zeiss Axioscope or Olympus Bx61 confocal microscope. Cell counting was performed with ImageJ software. Images sampling bregma 1.42-1.1 of NAc (core and shell) and dorsal striatum were taken from 2 or 3 brain sections/animal (see Fig. 1A). A total of 400-500 cells were counted per brain region per mouse using $250 \mu \mathrm{m} \times 250 \mu \mathrm{m}$ images. Cells were counted using ImageJ software similar to a previous study (Lobo et al., 2010). Approximately $400-500$ total NeuN cells were counted per brain region per mouse, and then the number of $\mathrm{GFP}^{+}, \mathrm{GFP}^{+}: \Delta \mathrm{FosB}^{+}$, $\mathrm{GFP}^{-}$, and $\mathrm{GFP}^{-}: \Delta \mathrm{FosB}^{+}$cells were counted in each region. Data were quantified as follows: $\left(\mathrm{GFP}^{+}: \Delta \mathrm{FosB}^{+}\right.$neurons $\left.\times 100 \%\right) /\left(\right.$ total $\mathrm{GFP}^{+}$ neurons) and $\left(\mathrm{GFP}^{-}: \Delta \mathrm{FosB}^{+}\right.$neurons $\left.\times 100 \%\right) /\left(\right.$ total $\mathrm{GFP}^{-}$neurons). Statistical analyses were performed using GraphPad Prism software. Two-way ANOVAs followed by Bonferroni post tests were used for all cell counting analyses.

\section{Results \\ $\Delta$ FosB is differentially induced in D1-MSNs and D2-MSNs after repeated exposure to cocaine versus haloperidol}

We first examined $\triangle$ FosB induction in MSN subtypes in D1-GFP and D2-GFP mice using chronic cocaine conditions previously shown to preferentially induce $\triangle$ FosB protein in D1-MSNs (Moratalla et al., 1996). D1-GFP and D2-GFP BAC transgenic mice, which express enhanced green fluorescent protein under the D1 
A

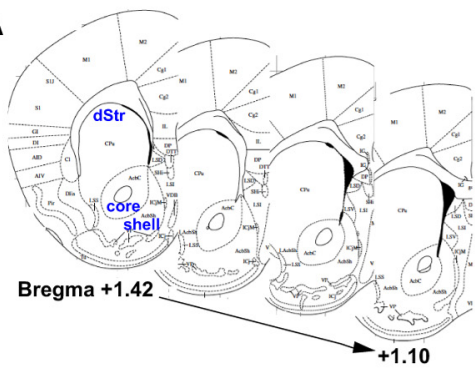

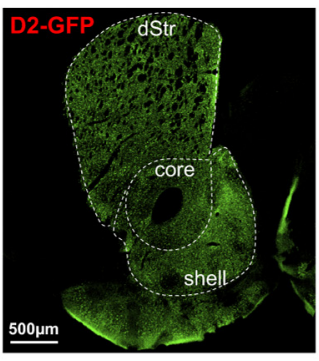

B

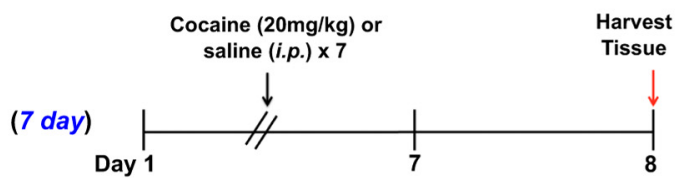

D $\square$ Saline
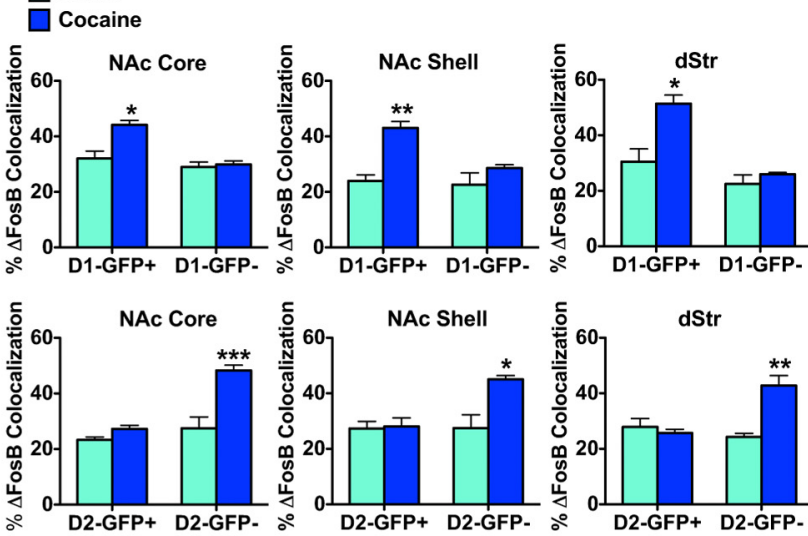

C

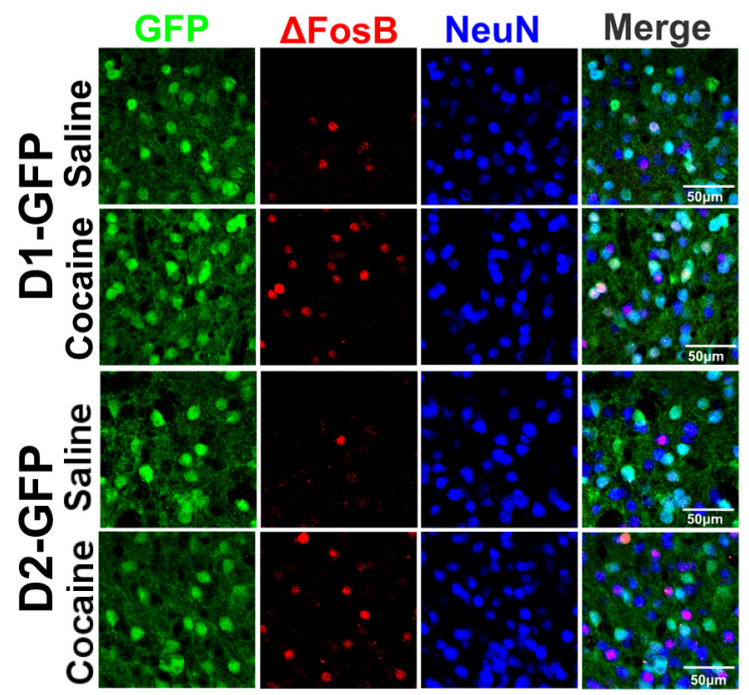

E

(1 day)

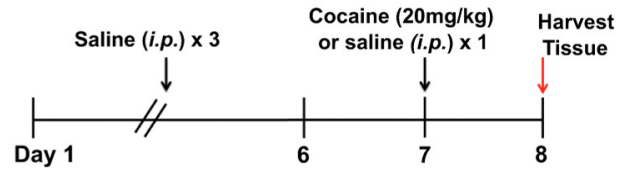

(3 day)

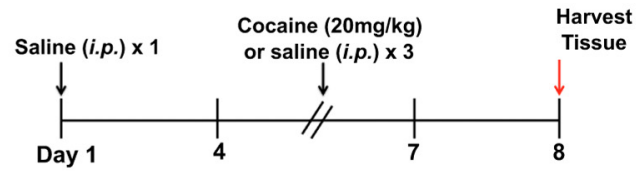

$\mathbf{F}$

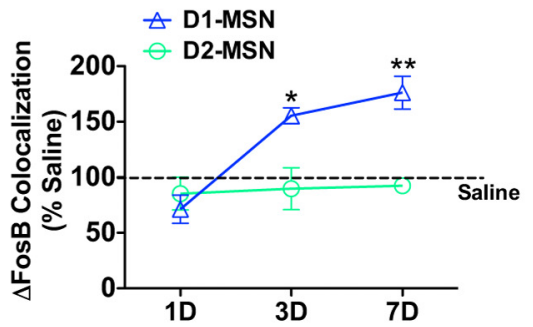

Figure 1. Chronic cocaine selectively induces $\triangle F$ osB in D1-MSNs in striatal regions. $A$, Striatal sections from bregma +1.42 to +1.10 were used for cell counting. Image of a D2-GFP striatal section demonstrates the three striatal regions studied: NAc core, NAc shell, and dStr. Scale bar, $500 \mu \mathrm{m}$. B. Time course of chronic (7 d) cocaine (20 mg/kg, i.p.) or saline treatment, with brains harvested $24 \mathrm{~h}$ after the last dose. C, Immunohistochemistry of NAc shell of D1-GFP and D2-GFP mice after chronic cocaine ( $20 \mathrm{mg} / \mathrm{kg}$, i.p) or saline. Immunolabeling for GFP (green), $\triangle$ FosB (red), or NeuN (blue) shows induction of $\triangle$ FosB in GFP ${ }^{+} / \mathrm{NeuN}^{+}$neurons in D1-GFPNAc shell or GFP ${ }^{-} / \mathrm{NeuN}^{+}$neurons in D2-GFPNAc shell. Scale bar, $50 \mu \mathrm{m}$. D, Cocaine treatment significantly induces $\triangle$ FosB in GFP ${ }^{+} / \mathrm{NeuN}^{+}$neurons (D1-MSNs) in D1-GFP mice but not in GFP ${ }^{-} / \mathrm{NeuN}^{+}$neurons (D2-MSNs) in the same mouse. Two-way ANOVA, NAc core: drug $\times$cell type $F_{(1,12)}=16.41, p<$ 0.05, Bonferroni post test: ${ }^{*} p<0.01$; NAc shell: drug $\times$ cell type $F_{(1,12)}=12.41, p<0.05$, Bonferroni post test: ${ }^{* *} p<0.001$; dStr: drug $\times$ cell type $F_{(1,12)}=12.07, p<0.05$, Bonferroni post test: ${ }^{*} p<0.01$. A significant induction of $\Delta$ FosB by cocaine is also observed in GFP ${ }^{-} / \mathrm{NeuN}^{+}$(D1-MSNs) but not GFP ${ }^{+} / \mathrm{NeuN}^{+}$neurons (D2-MSNs) in D2-GFP mice. Two-way ANOVA, NAc core: drug $\times$ cell type $F_{(1,12)}=15.76, p<0.01$, Bonferroni post test: ${ }^{* * *} p<0.0001$; NAc shell: drug $\times$ cell type: $F_{(1,12)}=20.33, p<0.05$, Bonferroni post test: ${ }^{*} p<0.01$; dStr: drug $\times$ cell type: $F_{(1,12)}=$ $35.96, p<0.01$, Bonferroni post test: ${ }^{* *} p<0.001$. $E$, Time course study of cocaine induction of $\Delta$ FosB in dStr. $F$, Cocaine significantly induces $\Delta$ FosB in D1-MSNs only after 3 or $7 \mathrm{~d}$ of cocaine exposure (two-way ANOVA, cell type $\times$ day $F_{(2,13)}=17.87, p<0.01$, Bonferroni post test: ${ }^{*} p<0.01,{ }^{* *} p<0.001$ ).

or $\mathrm{D} 2$ receptor gene (Fig. $1 A$ ), received intraperitoneal injections of cocaine $(20 \mathrm{mg} / \mathrm{kg}$ ) or saline for $7 \mathrm{~d}$, and brains were collected $24 \mathrm{~h}$ after the final injection (Fig. $1 B$ ). We then performed immunohistochemistry on brain sections using antibodies against NeuN, GFP, or FosB and imaged and counted cells in NAc core, NAc shell, and dStr (Fig. $1 A, C$ ). Whereas the anti-FosB antibody recognizes full-length FosB and $\Delta$ FosB, numerous studies using Western blotting or immunohistochemistry have confirmed that $\Delta$ FosB is the only detectable species present at the $24 \mathrm{~h}$ withdrawal time point (e.g., Perrotti et al., 2008). We therefore used the $24 \mathrm{~h}$ or longer time point to collect brains after all conditions in this study to ensure that we are only detecting $\Delta$ FosB. Because striatal MSNs comprise $\sim 95 \%$ of all neurons in striatum, we used NeuN immunolabeling to identify the $\mathrm{GFP}^{-}$neurons, which are enriched in the opposite MSN subtype (i.e., D2-MSNs in the D1-GFP mice and D1-MSNs in the D2-GFP mice). We found that $D 1-G F P$ mice treated with cocaine display a significant induction of $\Delta \mathrm{FosB}$ in $\mathrm{GFP}^{+} / \mathrm{NeuN}^{+}$neurons (D1-MSNs) in NAc core, NAc shell, and dStr, whereas $\mathrm{GFP}^{-} / \mathrm{NeuN}^{+}$cells (D2-MSNs) showed no significant induction of $\Delta$ FosB in all striatal regions (Fig. 1D): two-way ANOVA, NAc core: drug $\times$ cell type $F_{(1,12)}=$ 16.41, $p<0.05$, Bonferroni post test: $p<0.01$; NAc shell: drug $\times$ cell type $F_{(1,12)}=12.41, p<0.05$, Bonferroni post test: $p<0.001$; dStr: drug $\times$ cell type $F_{(1,12)}=12.07, p<0.05$, Bonferroni post test: $p<0.01$. Consistent with these findings, we observed in D2-GFP mice no significant induction of $\triangle \mathrm{FosB}$ in $\mathrm{GFP}^{+} /$ $\mathrm{NeuN}^{+}$neurons (D2-MSNs) but a significant induction of $\Delta$ FosB in $\mathrm{GFP}^{-} / \mathrm{NeuN}^{+}$(D1-MSNs) in all striatal regions after cocaine treatment (Fig. 1D): two-way ANOVA, NAc core: drug $\times$ cell type $F_{(1,12)}=15.76, p<0.01$, Bonferroni post test: $p<$ 0.0001; NAc shell: drug $\times$ cell type: $F_{(1,12)}=20.33, p<0.05$, Bonferroni post test: $p<0.01$; dStr: drug $\times$ cell type: $F_{(1,12)}=$ $35.96, p<0.01$, Bonferroni post test: $p<0.001$. We examined the kinetics of $\Delta$ FosB induction in MSNs after 1, 3, or $7 \mathrm{~d}$ of cocaine 
A

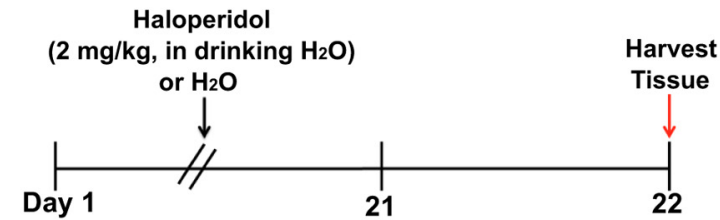

B

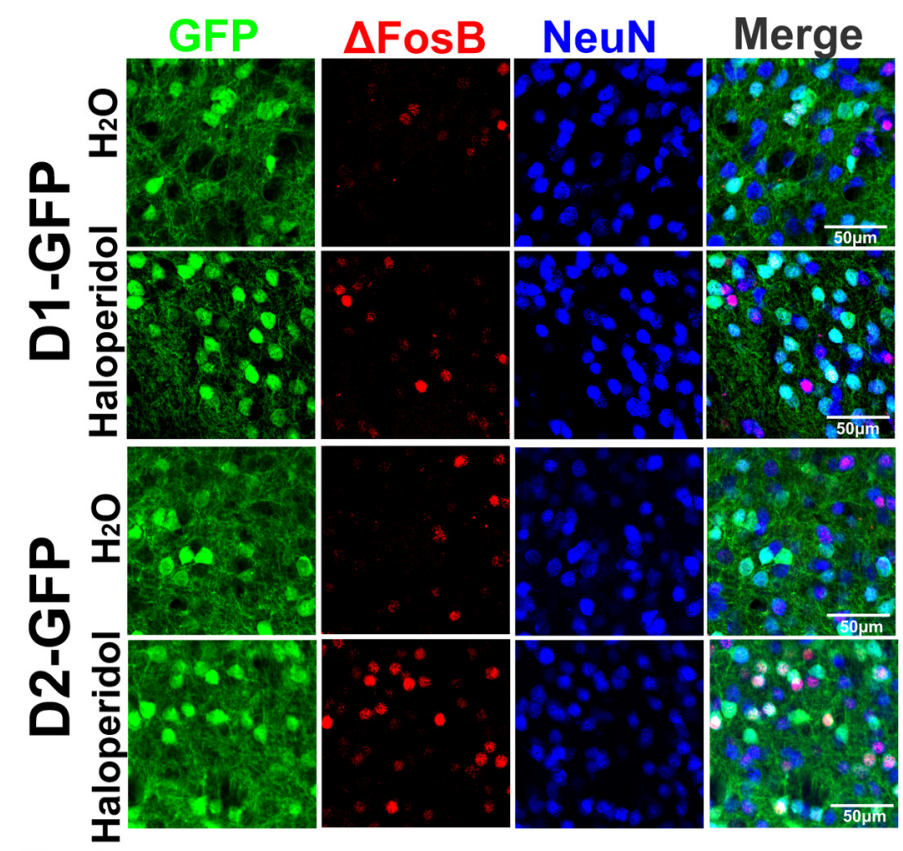

\section{C $\square \mathrm{H}_{2} \mathrm{O}$}
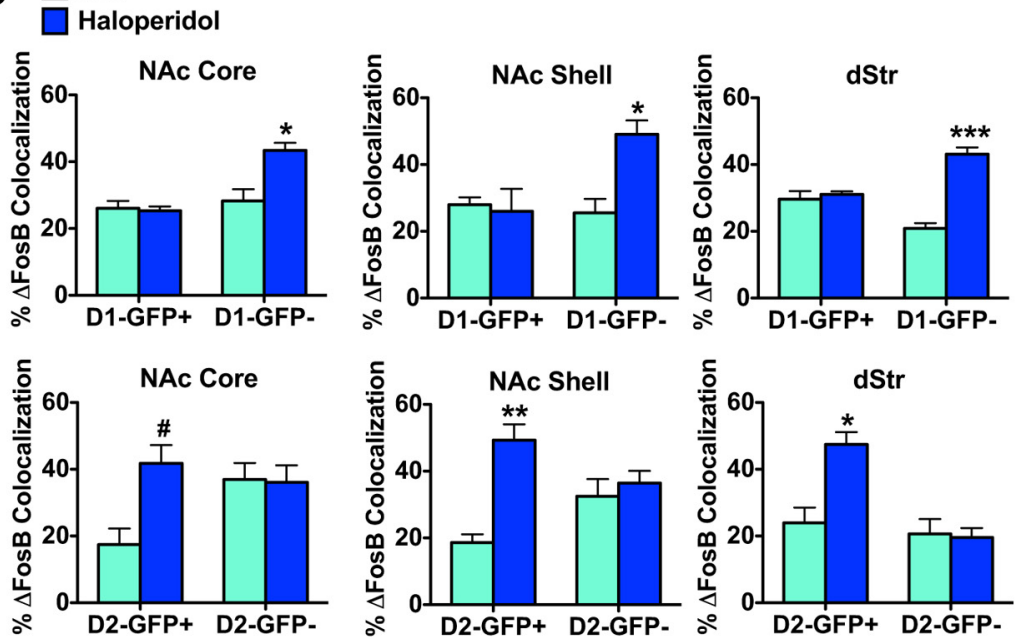

Figure 2. Chronic haloperidol selectively induces $\triangle F O S B$ in D2-MSNs in striatal regions. $\boldsymbol{A}$, Time course of $21 \mathrm{~d}$ treatment of haloperidol ( $2 \mathrm{mg} / \mathrm{kg}$, in the drinking water) or water. $\boldsymbol{B}$, Immunohistochemistry of NAc shell of D1-GFP and D2-GFP mice after haloperidol or water treatment. Immunolabeling for GFP (green), $\triangle$ FosB (red), or NeuN (blue) shows induction of $\Delta$ FosB in $\mathrm{GFP}^{-} / \mathrm{NeuN}^{+}$neurons in D1-GFP NAc shell or GFP ${ }^{+} / \mathrm{NeuN}^{+}$neurons in D2-GFP NAc shell. Scale bar, $50 \mu \mathrm{m}$. C, Haloperidol treatment significantly induces $\Delta$ FosB in $\mathrm{GFP}^{-} / \mathrm{NeuN}^{+}$neurons (D2-MSNs) in D1-GFP mice but not in GFP ${ }^{+} / \mathrm{NeuN}^{+}$neurons (D1-MSNs) in the same mouse. Two-way ANOVA, NAc core: drug $\times$ cell type: $F_{(1,10)}=23.29, p<0.05$, Bonferroni post test: ${ }^{*} p<$ 0.01; NAc shell: drug: drug $\times$ cell type: $F_{(1,10)}=30.14, p<0.05$, Bonferroni post test: ${ }^{*} p<0.01$; dStr: drug $\times$ cell type: $F_{(1,10)}$ $=37.63, p<0.001$, Bonferroni post test: ${ }^{* *} p<0.0001$. A significant induction of $\Delta$ FosB by haloperidol is also observed in $\mathrm{GFP}^{+} / \mathrm{NeuN}^{+}$(D2-MSNs) but not GFP ${ }^{-} / \mathrm{NeuN}^{+}$neurons (D1-MSNs) in D2-GFP mice. Two-way ANOVA, NAc core: drug $\times$cell type: $F_{(1,12)}=24.30, p<0.05$, Bonferroni post test: ${ }^{\#} p<0.05$; NAc shell: drug $\times$ cell type: $F_{(1,12)}=26.07, p<0.01$, Bonferroni post test: ${ }^{* *} p<0.001$; dStr: drug $\times$ cell type: $F_{(1,12)}=21.36, p<0.01$, Bonferroni post test: ${ }^{*} p<0.01$.

(20 mg/kg, i.p) injections. We observed a significant induction of $\Delta$ FosB in D1-MSNs with 3 or $7 \mathrm{~d}$ of cocaine treatment compared with saline treatment in all striatal regions (Fig. $1 F$ ): representative graph from dStr; two-way ANOVA, cell type $\times$ day $F_{(2,13)}=$
17.87, $p<0.01$, Bonferroni post test: $p<$ $0.01, p<0.001$. This is consistent with the time course of $\Delta \mathrm{FosB}$ accumulation in striatum seen earlier by Western blotting (Hope et al., 1994) and confirms the selective induction of $\triangle \mathrm{FosB}$ solely in $\mathrm{D} 1$ MSNs throughout a course of cocaine exposure.

We next examined $\Delta$ FosB induction by immunohistochemistry in MSN subtypes after chronic exposure to haloperidol (Fig. 2). Prior work suggested indirectly that chronic haloperidol might induce $\Delta$ FosB preferentially in D2-MSNs (Hiroi and Graybiel, 1996; Atkins et al., 1999), although this has heretofore not been examined directly. D1-GFP and D2GFP mice received haloperidol $(2 \mathrm{mg} / \mathrm{kg})$ in the drinking water, $\mathrm{pH} 6.0$, whereas D1-GFP and D2-GFP control mice received regular drinking water, $\mathrm{pH}$ 6.0, for $21 \mathrm{~d}$ (3 weeks) and brains were collected on day 22 (Fig. 2A). As with cocaine, we know that all FosB-like immunoreactivity in striatum at this time point represents $\Delta$ FosB, not full-length FosB (Atkins et al., 1999). We found that D1-GFP mice receiving haloperidol displayed no significant induction of $\triangle$ FosB in $\mathrm{GFP}^{+}$/ $\mathrm{NeuN}^{+}$neurons (D1-MSNs) in NAc core, NAc shell, or dStr; however, a significant increase in $\triangle \mathrm{FosB}$ was observed in $\mathrm{GFP}^{-} / \mathrm{NeuN}^{+}$neurons (D2-MSNs) in all striatal regions (Fig. 2B,C): two-way ANOVA, NAc core: drug $\times$ cell type: $F_{(1,10)}=23.29, p<0.05$, Bonferroni post test: $p<0.01$; NAc shell: drug: drug $\times$ cell type: $F_{(1,10)}=30.14, p<0.05$, Bonferroni post test: $p<0.01$; dStr: $\operatorname{drug} \times$ cell type: $F_{(1,10)}=37.63, p<0.001$, Bonferroni post test: $p<0.0001$. This was confirmed by examination of D2-GFP mice: we observed a significant induction of $\triangle F$ FosB in $\mathrm{GFP}^{+} / \mathrm{NeuN}^{+}$neurons (D2-MSNs) in all three striatal regions, but no significant change in $\Delta$ FosB in $\mathrm{GFP}^{-} / \mathrm{NeuN}^{+}$(D1MSNs) after haloperidol treatment (Fig. $2 B, C)$ : two-way ANOVA, NAc core: drug $\times$ cell type: $F_{(1,12)}=24.30, p<0.05$, Bonferroni post test: $p<0.05$; NAc shell: drug $\times$ cell type: $F_{(1,12)}=26.07, p<0.01$, Bonferroni post test: $p<0.001$; dStr: drug $\times$ cell type: $F_{(1,12)}=21.36, p<0.01$, Bonferroni post test: $p<0.01$. Given that we observed a similar pattern of $\triangle \mathrm{FosB}$ induction in D1-MSNs by repeated cocaine exposure in both D1-GFP $\left(\mathrm{GFP}^{+} /\right.$ $\left.\mathrm{NeuN}^{+}\right)$and D2-GFP $\left(\mathrm{GFP}^{-} / \mathrm{NeuN}^{+}\right)$ mice, and by repeated haloperidol in $\mathrm{D} 2-$ MSNs in D1-GFP $\left(\mathrm{GFP}^{-} / \mathrm{NeuN}^{+}\right)$and D2-GFP $\left(\mathrm{GFP}^{+} /\right.$ $\mathrm{NeuN}^{+}$) mice, the remainder of our experiments used D2-GFP mice to examine $\Delta$ FosB induction in D1-MSNs $\left(\mathrm{GFP}^{-} / \mathrm{NeuN}^{+}\right)$ and D2-MSNs $\left(\mathrm{GFP}^{+} / \mathrm{NeuN}^{+}\right)$after other chronic stimuli. 
As a control, we examined levels of CREB expression in the cocaine and haloperidol conditions to determine whether our findings could be generalized to other transcription factors (Fig. 3). We observed no significant difference in CREB expression between control and drugtreated mice. Further, we observed no difference in CREB levels between D2-MSNs and D1-MSNs (Fig. $3 \mathrm{~B}, \mathrm{C}$ ).

\section{Distinct patterns of $\Delta$ FosB induction in} MSN subtypes by drugs of abuse Because previous studies have demonstrated that other drugs of abuse can potently induce $\Delta$ FosB in striatal subregions (Perrotti et al., 2008), we examined $\Delta$ FosB in MSN subtypes after chronic exposure to opiates, EtOH, or $\Delta(9)$-THC. We first examined whether chronic morphine exposure induces $\Delta \mathrm{FosB}$ in specific $\mathrm{MSN}$ subtypes across striatal regions. D2-GFP mice received two subcutaneous implants of a sham or morphine $(25 \mathrm{mg}$ ) pellet on days 1 and 3 , and brains were collected on day 5 (Fig. $4 A$ ) when $\Delta$ FosB, but not FosB, is induced (Zachariou et al., 2006). In striking contrast to cocaine, both MSN subtypes displayed a significant (and approximately comparable) increase in $\Delta$ FosB in NAc core, NAc shell, and dStr in the morphine group compared with sham controls, with no differential cell subtype induction of $\triangle$ FosB seen across all striatal regions (Fig. 4A): two-way ANOVA; NAc core: drug $F_{(1,14)}=75.01, p<0.0001$, Bonferroni post test: $p<0.01$ (D2-MSN), $p<0.001$ (D1-MSN); NAc shell: drug $F_{(1,14)}=62.87, p<0.0001$, Bonferroni post test: $p<0.01$ (D2-MSN), $p<0.05$ (D1-MSN); dStr: drug $F_{(1,14)}=60.11, p<$ 0.001 , Bonferroni post test: $p<0.01$ (D2MSN), $p<0.05$ (D1-MSN).

We next investigated the pattern of induction of $\triangle$ FosB in MSN subtypes after chronic exposure to EtOH. D2-GFP mice were given a two bottle choice test for $10 \%$ EtOH (bottle A) and water (bottle B), whereas D2-GFP controls received water in both bottles (bottles $\mathrm{A}$ and $\mathrm{B}$ ), for $10 \mathrm{~d}$ and brains were collected on day 11 (Fig. 4B). Mice that received the $10 \% \mathrm{EtOH}$ bottle consumed significantly more EtOH compared with water, whereas mice receiving water in both bottles demonstrated no difference in liquid consumption (Fig. $4 B$ ): preference for bottle A water group: $50.00 \pm 4.551 \%$, EtOH group: $84.44 \pm 8.511 \%$; Student's $t$ test, $p<0.05$. Chronic EtOH administration resulted in a significant induction of $\Delta$ FosB selectively in D1-MSNs in NAc core, NAc shell, and dStr, with no change in D2-MSNs (Fig. 4B): two-way ANOVA, NAc core: drug $\times$ cell type: $F_{(1,14)}=24.58, p<0.05$, Bonferroni post test: $p<0.05$; NAc shell: drug $\times$ cell type: $F_{(1,14)}=$ $36.51, p<0.01$, Bonferroni post test: $p<0.01$; dStr: drug $\times$ cell type: $F_{(1,14)}=29.03, p<0.01$, Bonferroni post test: $p<0.01$.

D2-GFP mice were also treated with $\Delta(9)-\mathrm{THC}(10 \mathrm{mg} / \mathrm{kg}$, i.p.) twice daily for $7 \mathrm{~d}$, and brains were collected $24 \mathrm{~h}$ after the last

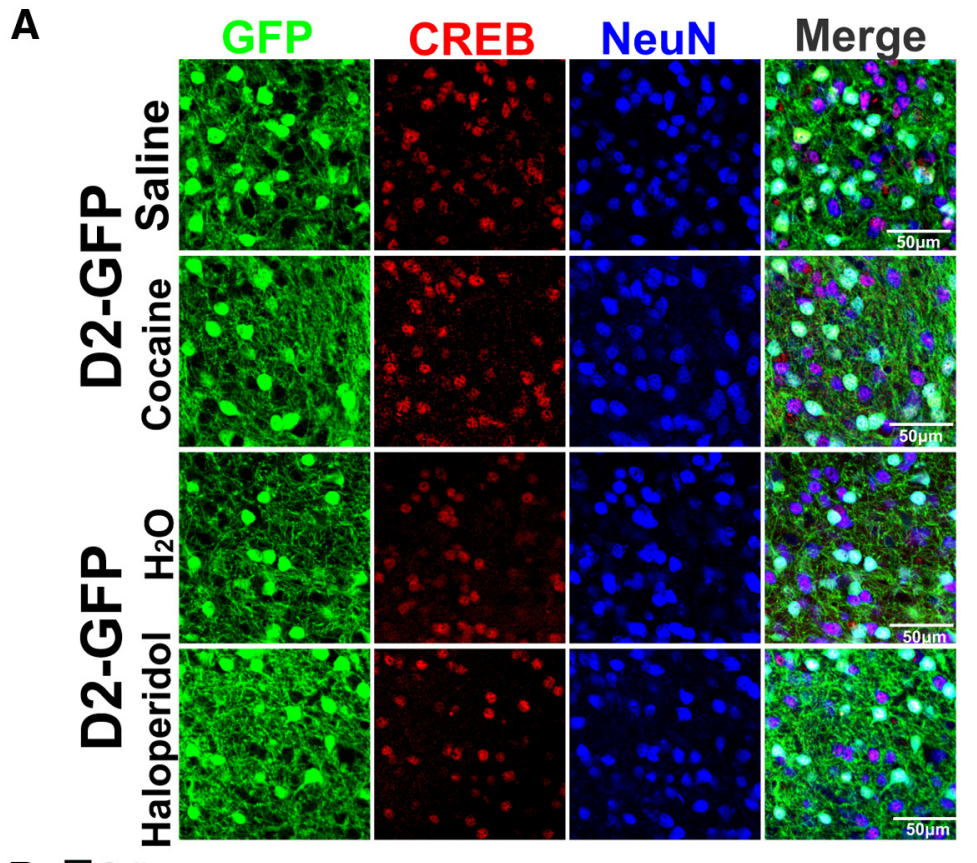

\section{$\square$ Cocaine}
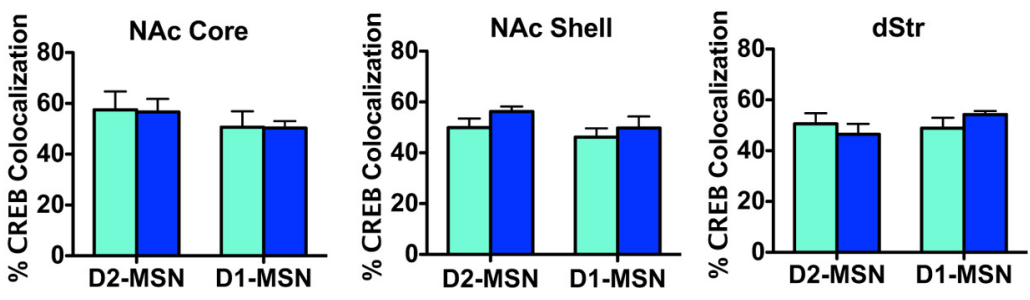
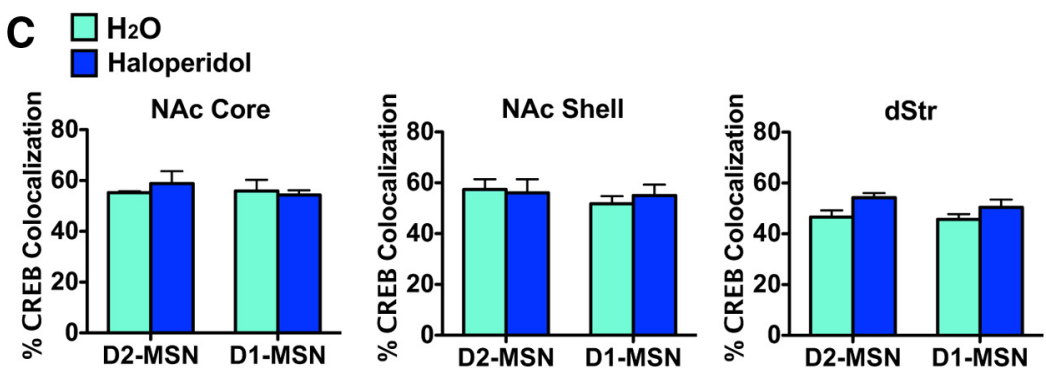

Figure 3. Chronic cocaine or haloperidol does not induce CREB in MSN subtypes. $A$, Immunostaining for CREB and GFP in striatum of D2-GFP mice after chronic cocaine or chronic haloperidol (Fig. 1 and 2 legends for drug treatments). Scale bar, $50 \mu \mathrm{m}$. $B, C$, Cocaine or haloperidol does not significantly induce CREB protein levels in D1-MSNs or D2-MSNs.

injection. Similar to the cocaine and $\mathrm{EtOH}$ conditions, we observed a significant increase in $\triangle$ FosB selectively in D1MSNs in all striatal regions in mice receiving chronic $\Delta(9)$ THC (Fig. 3E): two-way ANOVA, NAc core: drug $\times$ cell type $F_{(1,8)}=26.37, p<0.01$, Bonferroni post test: $p<0.01$; NAc shell: drug $\times$ cell type: $F_{(1,8)}=44.49, p<0.05$, Bonferroni post test: $p<0.001$; dStr: drug $\times$ cell type $F_{(1,8)}=29.30, p<$ 0.05, Bonferroni post test: $p<0.01$.

We next examined whether the observed pattern of $\Delta$ FosB induction in MSN subtypes by investigator administration of cocaine or opiates occurs in contingent paradigms in which mice volitionally self-administer the drug. First, D2-GFP mice were trained to self-administer cocaine $(0.5 \mathrm{mg} / \mathrm{kg} /$ infusion $)$ on an FR1 schedule for $2 \mathrm{~h}$ a day for 3 weeks and brains were collected $24 \mathrm{~h}$ after the last infusion (Fig. $4 D$ ), when $\Delta$ FosB, but not FosB, is known to be induced (Larson et al., 2010). Mice spent signifi- 

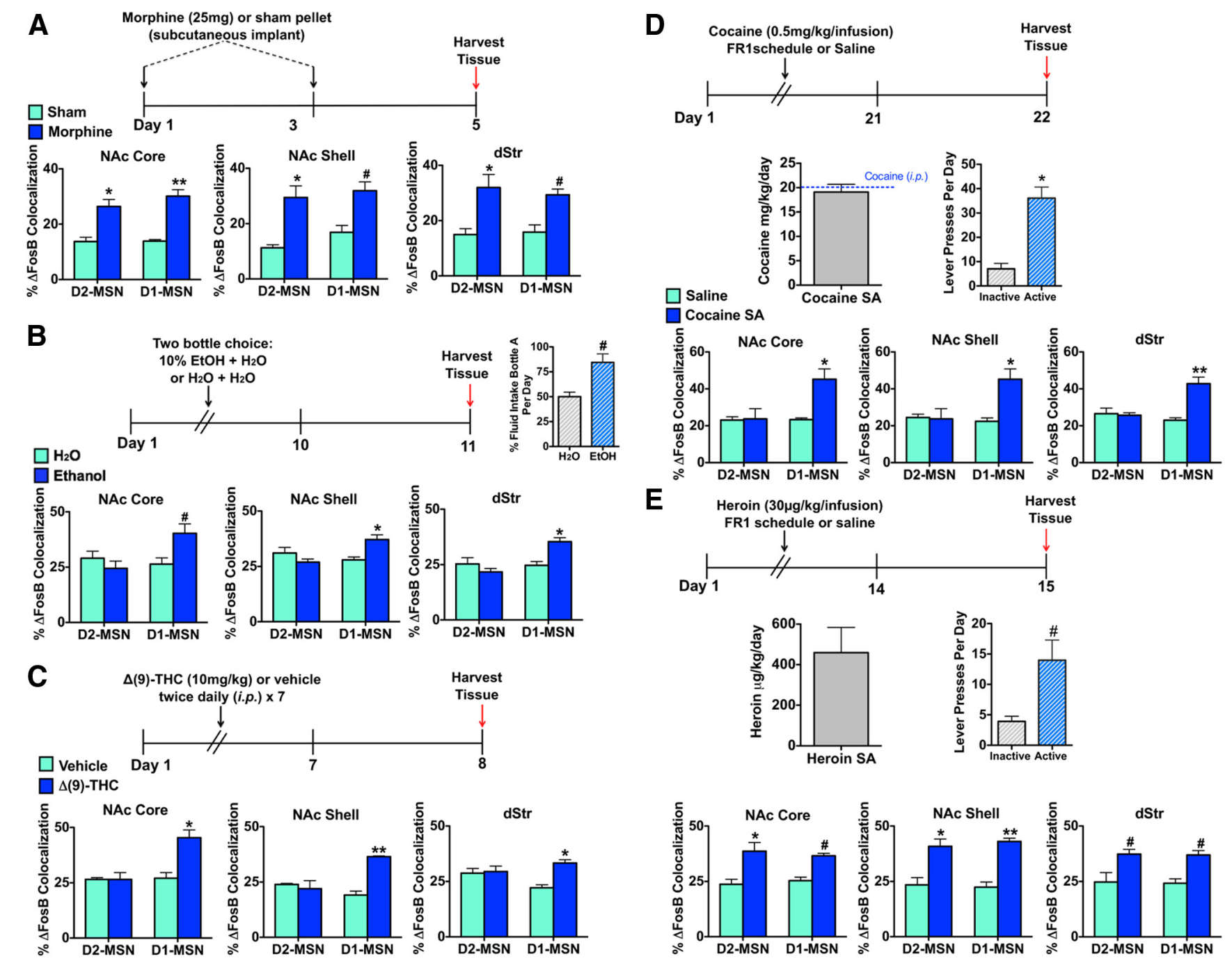

Figure 4. Drugs of abuse induce $\Delta$ FosB in MSN subtypes in striatal regions. $A$, Chronic morphine treatment (25 mg pellets on days 1 and 3 ) in D2-GFP mice results in significant induction of $\Delta$ FosB in both MSN subtypes in NAc core, NAc shell, and dStr compared with sham-treated D2-GFP mice. Two-way ANOVA, NAc core: $\operatorname{drug} F_{(1,14)}=75.01, p<0.0001$, Bonferroni post test: ${ }^{p} p<0.01$ (D2-MSN), ${ }^{* *} p<0.001$ (D1-MSN); NAc shell: drug $F_{(1,14)}=62.87, p<0.0001$, Bonferroni post test: ${ }^{*} p<0.01$ (D2-MSN), ${ }^{\#} p<0.05$ (D1-MSN); dStr: drug $F_{(1,14)}=60.11, p<0.001$, Bonferroni post test: ${ }^{*} p<0.01$ (D2-MSN), ${ }^{\#} p<0.05$ (D1-MSN). B, D2-GFP mice that demonstrated a preference for $10 \% \mathrm{Et} 0 \mathrm{H}$, in the drinking water over $10 \mathrm{~d}$ with mice examined $24 \mathrm{~h}$ after the last session, exhibited a significant increase in $\triangle$ FosB in D1-MSNs in all striatal regions compared with D2-GFP mice receiving only water. Two-way ANOVA, NAc core: drug $\times$ cell type: $F_{(1,14)}=24.58, p<0.05$, Bonferroni post test: ${ }^{\#} p<0.05$; NAc shell: drug $\times$ cell type: $F_{(1,14)}=36.51, p<0.01$, Bonferroni post test: ${ }^{*} p<0.01$; dStr: drug $\times$ cell type: $F_{(1,14)}=29.03, p<0.01$, Bonferroni post test: ${ }^{*} p$ $<0.01$. C, Chronic $\Delta(9)$-THC (10 mg/kg, i.p.), twice a day for $7 \mathrm{~d}$ with mice examined $24 \mathrm{~h}$ after the last treatment, in D2-GFP mice, resulted in a significant induction of $\Delta$ FosB in D1-MSNs in all striatal regions compared with D2-GFP mice that received vehicle only. Two-way ANOVA, NAc core: drug $\times$ cell type: $F_{(1,8)}=26.37, p<0.01$, Bonferroni post test: ${ }^{*} p<0.01$; NAc shell: drug $\times$ cell type: $F_{(1,8)}=44.49, p<0.05$, Bonferroni post test: ${ }^{* *} p<0.001$; dStr: drug $\times$ cell type: $F_{(1,8)}=29.30, p<0.05$, Bonferroni post test: $\left.{ }^{*} p<0.01\right)$. $D$, Cocaine self-administration $(50$ $\mu \mathrm{g} / \mathrm{kg} /$ infusion, $2 \mathrm{~h} / \mathrm{d}$ ), using an FR1 schedule for 3 weeks with mice examined $24 \mathrm{~h}$ after the last session, in D2-GFP mice, resulted in significant induction of $\triangle$ FosB in D1-MSNs across all striatal regions. Two-way ANOVA, NAc core: drug $\times$ cell type: $F_{(1,14)}=21.75, p<0.05$, Bonferroni post test: ${ }^{*} p<0.01$; NAc shell: drug $\times$ cell type: $F_{(1,14)}=26.52, p<0.01$, Bonferroni post test: ${ }^{*} p<$ 0.01 ; dStr: drug $\times$ cell type $F_{(1,14)}=33.68, p<0.001$, Bonferroni post test: ${ }^{* *} p<0.001$. The average daily dose of cocaine was $19.1 \mathrm{mg} / \mathrm{kg}$, and mice spent more time on the active versus inactive lever. Student's t test, ${ }^{*} p<0.01$. E, Heroin self-administration $(30 \mu \mathrm{g} / \mathrm{kg} / \mathrm{infusion}, 3 \mathrm{~h} / \mathrm{d})$, using an FR1 schedule for 2 weeks with mice examined $24 \mathrm{~h}$ after the last session, in D2-GFP mice, resulted in significant induction of $\triangle$ FosB in both D2-MSNs and D1-MSNs across all striatal regions. Two-way ANOVA, NAc core: $\operatorname{drug} F_{(1,12)}=68.88, p<0.001$, Bonferroni post test: * $p<0.01$ (D2-MSN), ${ }^{\#} p<0.05$ (D1-MSN); NAc shell: $\operatorname{drug} F_{(1,12)}=80.08, p<0.0001$, Bonferroni post test: ${ }^{*} p<0.01$ (D2-MSN), ${ }^{* *} p<0.001$ (D1-MSN); dStr: drug $F_{(1,12)}=63.36, p<0.001$, Bonferroni post test: ${ }^{\#} p<0.05$ (D2-MSN), $p<0.05$ (D1-MSN). The average daily dose of heroin was $0.459 \mathrm{mg} / \mathrm{kg}$, and mice spent more time on the active versus inactive lever. Student's $t$ test, ${ }^{\#} p<0.05$.

cantly more time pressing the active versus inactive lever (Fig. $4 D$; Student's $t$ test, $p<0.01)$. The average daily dose of cocaine was $19.1 \mathrm{mg} / \mathrm{kg}$ intravenously (Fig. $4 D$ ), similar to the $20 \mathrm{mg} / \mathrm{kg}$ intraperitoneal dose used above (Fig. 1). As with noncontingent cocaine exposure (Fig. 1), we found that cocaine selfadministration caused a significant induction of $\Delta \mathrm{FosB}$ only in D1-MSNs in all striatal regions compared with saline exposure (Fig. $4 D$ ): two-way ANOVA, NAc core: drug $\times$ cell type $F_{(1,14)}=$ 21.75, $p<0.05$, Bonferroni post test: $p<0.01$; NAc shell: drug $\times$ cell type: $F_{(1,14)}=26.52, p<0.01$, Bonferroni post test: $p<0.01$;
dStr: drug $\times$ cell type $F_{(1,14)}=33.68, p<0.001$, Bonferroni post test: $p<0.001$. Likewise, similarly to noncontingent opiate (morphine) exposure (Fig. $4 A$ ), we found that D2-GFP mice that selfadministered heroin (30 $\mu \mathrm{g} / \mathrm{kg}$ per infusion), on an FR1 schedule $3 \mathrm{~h}$ a day for 2 weeks examined $24 \mathrm{~h}$ after the last drug exposure, displayed significant $\triangle$ FosB induction in both D2-MSNs and D1MSNs in all striatal regions (Fig. $4 E$ ): two-way ANOVA, NAc core: drug $F_{(1,12)}=68.88, p<0.001$, Bonferroni post test: $p<$ 0.01 (D2-MSN), $p<0.05$ (D1-MSN); NAc shell: drug $F_{(1,12)}=$ $80.08, p<0.0001$, Bonferroni post test: $p<0.01$ (D2-MSN), $p<$ 
0.001 (D1-MSN); dStr: drug $F_{(1,12)}=$ 63.36, $p<0.001$, Bonferroni post test: $p<$ 0.05 (D2-MSN), $p<0.05$ (D1-MSN). The average daily dose for heroin was 0.459 $\mathrm{mg} / \mathrm{kg}$, and mice spent significantly more time pressing the active versus inactive lever (Student's $t$ test, $p<0.05$ ) (Fig. $4 E$ ).

\section{Environmental enrichment and} appetitive stimuli induce $\Delta$ FosB in both D1-MSNs and D2-MSNs

Because previous studies demonstrated that natural rewards induce $\Delta$ FosB in striatal regions (Werme et al., 2002; Teegarden and Bale, 2007; Wallace et al., 2008; Solinas et al., 2009; Vialou et al., 2011), with induction by wheel running selective for D1-MSNs (Werme et al., 2002), we examined whether induction by other natural rewards demonstrated cellular specificity. We first used a juvenile enrichment paradigm in which D2-GFP mice were housed in an enriched environment from weaning ( 3 weeks) for a 4 week period (Fig. $5 A$ ). This approach was previously shown to induce $\Delta$ FosB in mouse NAc and dStr (Solinas et al., 2009; Lehmann and Herkenham, 2011). Compared with normal housing conditions, the enriched environment significantly increased $\Delta$ FosB in all striatal regions but did not do so in a cell type-specific manner, with comparable induction seen in D1-MSNs and D2-MSNs (Fig. 5A): twoway ANOVA, NAc core: environment $F_{(1,12)}=89.13, p<0.0001$, Bonferroni post test: $p<0.0001$ (D2-MSN), $p<$ 0.0001 (D1-MSN); NAc shell: environment $F_{(1,12)}=80.50, p<0.0001$, Bonferroni post test: $p<0.001$ (D2-MSN), $p<0.001$ (D1-MSN); dStr: environment $F_{(1,12)}=56.42, p<0.01$, Bonferroni post test: $p<0.05$ (D2-MSN), $p<$ 0.05 (D1-MSN).

We next examined $\Delta$ FosB expression in MSN subtypes after chronic appetitive stimuli. We first tested the effects of chronic sucrose drinking, which was previously demonstrated to induce $\Delta$ FosB in rat NAc (Wallace et al., 2008). D2-GFP mice were given a two bottle choice test for $10 \%$ sucrose (bottle A) and water (bottle B), whereas D2-GFP controls received water in both bottles (bottle A and B) for $10 \mathrm{~d}$ and brains were collected on day 11 (Fig. 5B). Mice that received $10 \%$ sucrose consumed significantly more sucrose, whereas mice receiving water in both bottles demonstrated no difference in liquid consumption (Fig. 5B): preference for bottle A, water: $50.00 \pm 4.749 \%$, sucrose: $89.66 \pm 4.473 \%$; Student's $t$ test, $p<$ 0.001 . We found that chronic sucrose
A
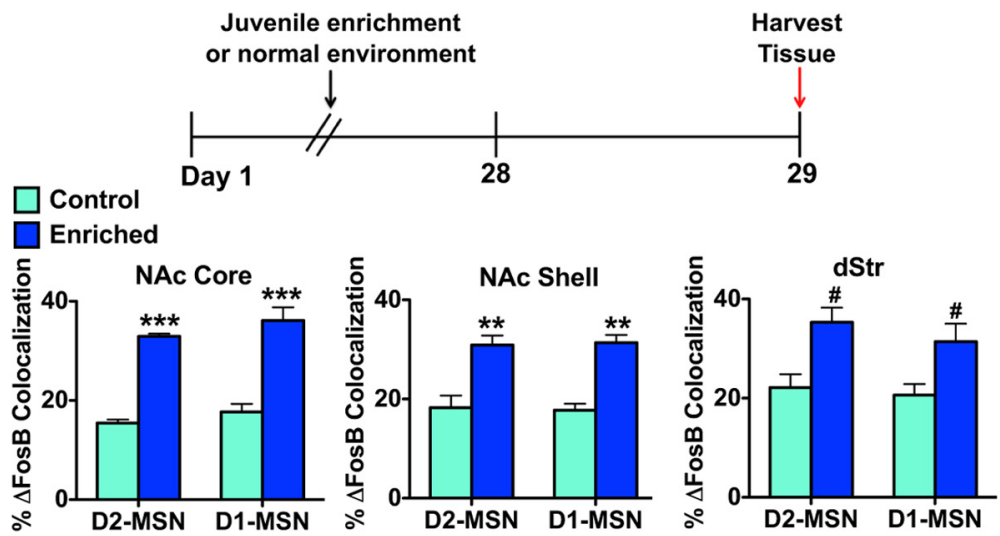

B
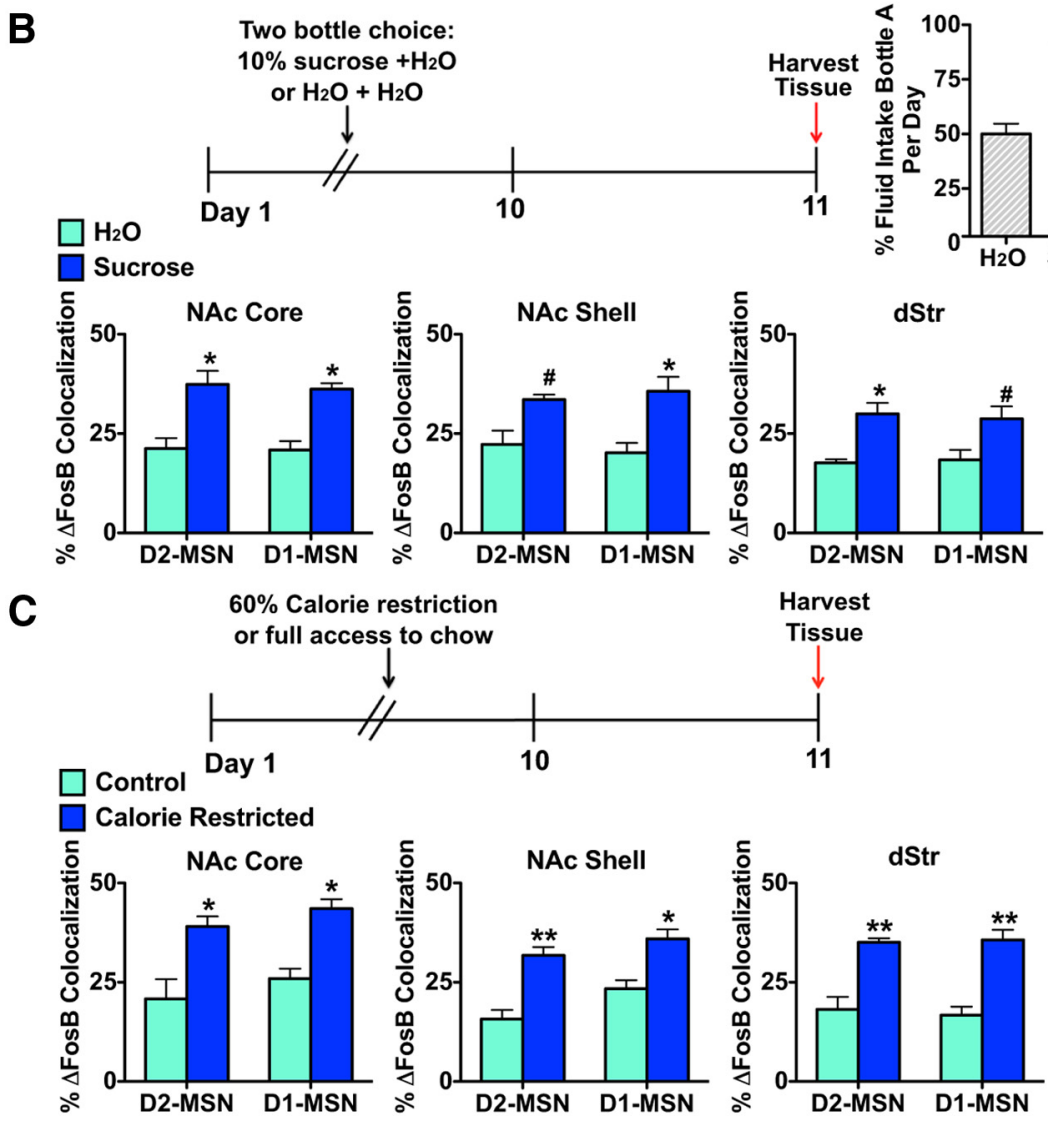

Figure 5. Environmental enrichment and appetitive stimuli induce $\triangle$ FosB in both MSN subtypes. $A, D 2-G F P$ mice that were housed in an enriched environment beginning at P21 for 4 weeks exhibit induction of $\triangle$ Fos B in both MSN subtypes across all striatal regions compared with D2-GFP mice in normal housing conditions. Two-way ANOVA, NAc core: environment $F_{(1,12)}=89.13 p<0.0001$, Bonferroni post test: ${ }^{* * *} p<0.0001$ (D2-MSN), ${ }^{* * *} p<0.0001$ (D1-MSN); NAc shell: environment $F_{(1,12)}=80.50, p<0.0001$, Bonferroni post test: ${ }^{* *} p<0.001$ (D2-MSN), ${ }^{* *} p<0.001$ (D1-MSN); dStr: environment $F_{(1,12)}=56.42, p<0.01$, Bonferroni post test: ${ }^{\#} p<0.05$ (D2-MSN), ${ }^{\#} p<0.05$ (D1-MSN). B, D2-GFP mice that exhibit a preference for $10 \%$ sucrose, in the drinking water over $10 \mathrm{~d}$ with mice examined $24 \mathrm{~h}$ after the last session, display a significant induction of $\triangle$ FosB in both MSN subtypes across all striatal regions compared with D2-GFP mice receiving water only. Two-way ANOVA, NAc core: treatment $F_{(1,12)}=76.15, p<0.0001$, Bonferroni post test: ${ }^{*} p<0.01$ (D2-MSN), ${ }^{*} p<0.01$ (D1-MSN); NAc shell: treatment $F_{(1,12)}=63.35, p<0.001$, Bonferroni post test: ${ }^{\#} p<0.05$ (D2-MSN), ${ }^{*} p<0.01$ (D1-MSN); dStr: treatment $F_{(1,12)}=63.36, p<0.001$, Bonferroni post test: ${ }^{*} p<0.01$ (D2-MSN), ${ }^{\#} p$ $<0.05$ (D1-MSN). Mice given the sucrose and water choice drank significantly more sucrose (bottle A) compared with mice with two water choices. Student's $t$ test, ${ }^{* *} p<0.001$. C, D2-GFP mice that underwent calorie restriction, receiving only $60 \%$ of ad libitum calories daily for $10 \mathrm{~d}$, followed by $24 \mathrm{~h}$ of free access to regular chow, displayed induction of $\Delta$ FosB in both MSN subtypes across all striatal regions compared with D2-GFP mice receiving free access to regular chow. Tw0-way ANOVA, NAc core: treatment $F_{(1,12)}=67.94 p<0.0001$, Bonferroni post test: ${ }^{*} p<0.01$ (D2-MSN), ${ }^{*} p<0.01$ (D1-MSN); NAc shell: treatment $F_{(1,12)}=67.84, p<0.0001$, Bonferroni post test: ${ }^{* *} p<0.001$ (D2-MSN), ${ }^{*} p<0.01$ (D1-MSN); dStr: treatment $F_{(1,12)}=82.70, p<0.0001$, Bonferroni post test: ${ }^{* *} p<0.001$ (D2-MSN), ${ }^{* *} p<0.001$ (D1-MSN). 
A
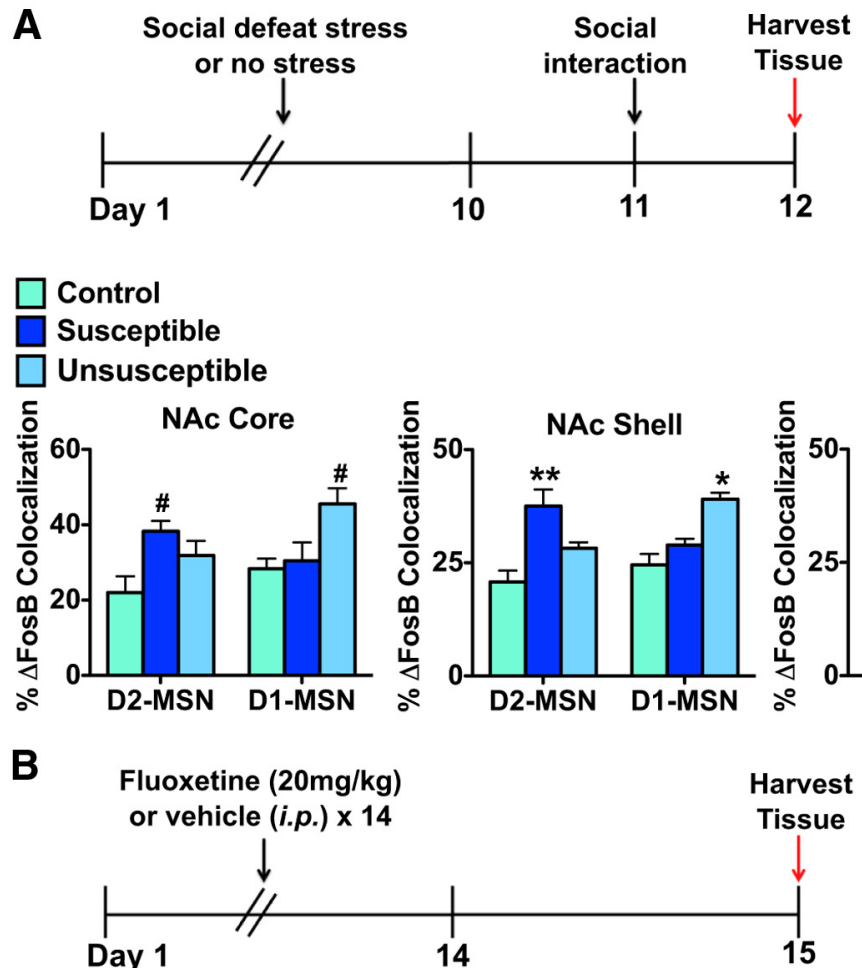

B
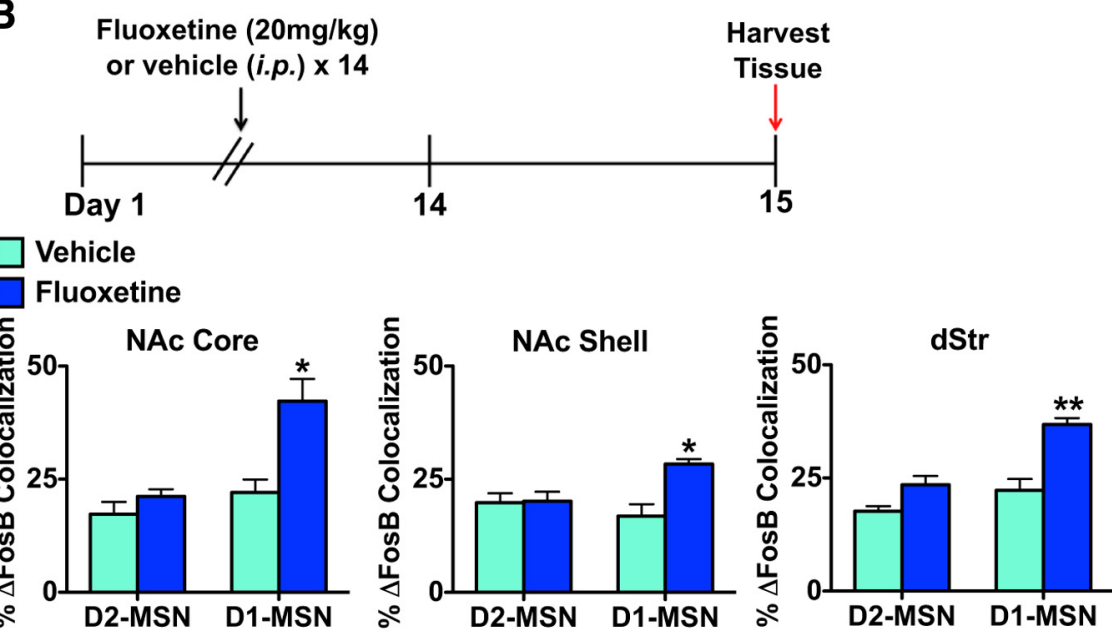

Figure 6. Chronic social defeat stress and chronic fluoxetine cause $\triangle$ FosB induction in distinct MSN subtypes in striatum. $\boldsymbol{A}$, D2-GFP that are susceptible to a $10 \mathrm{~d}$ course of social defeat stress exhibit $\Delta$ FosB induction in D2-MSNs in all striatal regions, $48 \mathrm{~h}$ after the last defeat episode and $24 \mathrm{~h}$ after the social interaction test, compared with control mice or mice that are resilient to $10 \mathrm{~d}$ of social defeat stress. Resilient D2-GFP mice exhibit induction of $\Delta$ Fos B in D1-MSNs in all striatal regions, $48 \mathrm{~h}$ after the last defeat episode, compared with control or susceptible mice. Two-way ANOVA, NAc core: group $\times$ cell type $F_{(1,20)}=20.11, p<0.05$, Bonferroni post test: D2-MSN/susceptible ${ }^{\#} p<0.05$, D1-MSN/resilient; ${ }^{*} p<0.05$; NAc shell: group $\times$ cell type $F_{(1,20)}=27.79$, $p<0.01$, Bonferroni post test:D2-MSN/susceptible; ${ }^{* *} p<0.001$, D1-MSN/resilient; ${ }^{*} p<0.01$; dStr: group $\times$ cell type $F_{(1,20)}=$ 19.76, $p<0.01$, Bonferroni post test: D2-MSN/susceptible; ${ }^{\#} p<0.05$, D1-MSN/resilient; ${ }^{*} p<0.01$. B, D2-GFP mice receiving chronic treatment of the fluoxetine $(20 \mathrm{mg} / \mathrm{kg}$, i.p.), for 2 weeks with mice examined $24 \mathrm{~h}$ after the last treatment, exhibit a significant induction of $\Delta$ FosB in D1-MSNs in all striatal regions. Tw0-way ANOVA, NAc core: drug $\times$ cell type $F_{(1,10)}=14.59, p<$ 0.05, Bonferroni post test: ${ }^{*} p<0.01$; NAc shell: drug $\times$ cell type: $F_{(1,10)}=26.14, p<0.05$, Bonferroni post test: ${ }^{*} p<0.01$; dStr: drug $\times$ cell type $F_{(1,10)}=8.19, p<0.05$, Bonferroni post test: ${ }^{* *} p<0.001$.

consumption induced $\triangle \mathrm{FosB}$ in NAc core, NAc shell, and dStr and that this occurred in both MSN subtypes (Fig. 5B): two-way ANOVA, NAc core: treatment $F_{(1,12)}=76.15 p<0.0001$, Bonferroni post test: $p<0.01$ (D2-MSN), $p<0.01$ (D1-MSN); NAc shell: treatment $F_{(1,12)}=63.35, p<0.001$, Bonferroni post test: $p<0.05$ (D2-MSN), $p<0.01$ (D1-MSN); dStr: treatment $F_{(1,12)}=63.36, p<0.001$, Bonferroni post test: $p<0.01$ (D2MSN), $p<0.05$ (D1-MSN).

Finally, we examined $\Delta$ FosB expression in MSN subtypes after calorie restriction because this condition, which increases locomotor activity and motivational state, was previously shown to enhance $\Delta$ FosB levels in mouse NAc (Vialou et al., 2011). D2GFP mice went through a calorie-restricted protocol, in which they received $60 \%$ of ad libitum calories daily for $10 \mathrm{~d}$ and brains were collected on day 11 (Fig. 5C). Calorie restriction increased $\triangle$ FosB levels in NAc core and NAc shell as previously demonstrated (Vialou et al., 2011) and also increased $\Delta$ FosB levels in dStr. However, we observed no differential induction in D1-MSNs versus D2-MSNs (Fig. 5C): two-way ANOVA, NAc core: treatment $F_{(1,12)}=67.94 p<$ 0.0001, Bonferroni post test: $p<0.01$ (D2-MSN), $p<0.01$ (D1-MSN); NAc shell: treatment $F_{(1,12)}=67.84, p<$ 0.0001 , Bonferroni post test: $p<0.001$ (D2-MSN), $p<0.01$ (D1-MSN); dStr: treatment $F_{(1,12)}=82.70, p<0.0001$, Bonferroni post test: $p<0.001$ (D2MSN), $p<0.001$ (D1-MSN).

\section{Chronic social defeat stress and antidepressant treatment cause differential induction of $\Delta$ FosB in MSN subtypes}

We previously demonstrated that $\Delta$ FosB is increased in NAc of mice after chronic social defeat stress (Vialou et al., 2010). Although this induction was observed in both susceptible mice (those that show deleterious sequelae of the stress) as well as in mice that are resilient (those that escape most of these deleterious effects), $\Delta$ FosB induction was greater in the resilient subgroup and was shown directly to mediate a state of resilience. In the present study, we found striking cellular specificity for $\Delta \mathrm{FosB}$ induction in these two phenotypic groups. D2-GFP mice were subjected to $10 \mathrm{~d}$ of social defeat stress and separated into susceptible and resilient populations based on a measure of social interaction (Fig. 6A), which correlates highly with other behavioral symptoms (Krishnan et al., 2007). Mice that developed susceptible behaviors after social defeat stress displayed a significant induction of $\triangle$ FosB in D2-MSNs in NAc core, NAc shell, and dStr compared with control and resilient mice, with no induction apparent in D1-MSNs. In striking contrast, resilient mice displayed significant $\Delta$ FosB induction in D1-MSNs across all striatal regions compared with susceptible and control mice, with no induction apparent in D2-MSNs (Fig. 6A; two-way ANOVA, NAc core: group $\times$ cell type $F_{(1,20)}=20.11, p<0.05$, Bonferroni post test: D2-MSN/susceptible $p<0.05$, D1-MSN/resilient $p<0.05$; NAc shell: group $\times$ cell type $F_{(1,20)}=27.79, p<0.01$, Bonferroni post test: D2-MSN/susceptible $p<0.001, \mathrm{D} 1-\mathrm{MSN} /$ resilient $p<0.01$; dStr: group $\times$ cell type $F_{(1,20)}=19.76, p<0.01$, Bonferroni post test: D2-MSN/susceptible $p<0.05$, D1-MSN/resilient $p<0.01$ ).

Chronic treatment with the SSRI antidepressant, fluoxetine, reverses the depression-like behaviors exhibited by susceptible mice after chronic social defeat stress (Berton et al., 2006). Moreover, such treatment induces $\Delta$ FosB in NAc of susceptible as well 
as control mice, and we have shown that such induction is required for fluoxetine's beneficial behavioral effects (Vialou et al., $2010)$. We thus examined the cellular specificity of $\Delta$ FosB induction after chronic fluoxetine administration. D2-GFP mice received fluoxetine $(20 \mathrm{mg} / \mathrm{kg}$, i.p.) for $14 \mathrm{~d}$, and brains were collected on day 15 (Fig. 6B). We observed a significant induction of $\Delta$ FosB in D1-MSNs, but not in D2-MSNs, in fluoxetinetreated mice compared with vehicle controls (Fig. 6B; two-way ANOVA, NAc core: drug $\times$ cell type $F_{(1,10)}=14.59, p<0.05$, Bonferroni post test: $p<0.01$; NAc shell: drug $\times$ cell type: $F_{(1,10)}=26.14, p<0.05$, Bonferroni post test: $p<0.01$; dStr: drug $\times$ cell type $F_{(1,10)}=8.19, p<0.05$, Bonferroni post test: $p<0.001)$.

\section{In vivo optogenetic manipulation of NAc afferent brain regions causes distinct patterns of $\Delta$ FosB induction in striatal regions and MSN subtypes}

Given that dopaminergic and glutamatergic afferent inputs to NAc can facilitate reward seeking and alter depression-like behaviors (Tsai et al., 2009; Covington et al., 2010; Adamantidis et al., 2011; Witten et al., 2011; Britt et al., 2012; Lammel et al., 2012; Stuber et al., 2012; Chaudhury et al., 2013; Kumar et al., 2013; Tye et al., 2013), we examined $\Delta$ FosB induction in striatal MSN subtypes after manipulating activity of several key afferent brain regions. We virally expressed ChR2 in each of several regions and activated them with blue light $(473 \mathrm{~nm})$ as described previously (Gradinaru et al., 2010; Yizhar et al., 2011). Because a recent study demonstrated that phasic stimulation with blue light, after non-cell-selective expression of ChR2 in VTA, resulted in the same behavioral phenotype as selective ChR2 phasic stimulation of VTA dopamine neurons (Chaudhury et al., 2013), we expressed ChR2 using AAV-hsyn-ChR2-EYFP in VTA of D2-GFP mice; control mice were injected with AAV-hsyn-EYFP. VTA sections were coimmunostained with tyrosine hydroxylase and GFP to visualize ChR2-EYFP expression (Fig. 7C). D2-GFP mice expressing ChR2-EFYP or EYFP alone in VTA received $5 \mathrm{~d}$ of 10 min of blue light phasic stimulation of the VTA as described previously (Koo et al., 2012; Chaudhury et al., 2013) (Fig. 7A), and brains were collected $24 \mathrm{~h}$ after the last stimulation. There was no desensitization of the ability of ChR2 to activate VTA dopamine neurons after $5 \mathrm{~d}$ of stimulation (Fig. $7 B$ ). We found that repeated phasic stimulation of VTA neurons expressing ChR2-EYFP increases $\triangle$ FosB in both MSN subtypes in NAc core, but only in D1-MSNs in NAc shell (Fig. 7C; two-way ANOVA, NAc core: optogenetic stimuli $F_{(1,16)}=51.97, p<0.0001$, Bonferroni post test: $p<0.001$; (both MSN subtypes) NAc shell: optogenetic stimuli $\times$ cell type: $F_{(1,16)}=13.82, p<0.05$, Bonferroni post test: $p<0.01)$. We observed no induction of $\Delta$ FosB in dStr after blue light phasic stimulation to VTA-expressing ChR2EYFP compared with EYFP controls. These results should be interpreted with caution, as we did not selectively target VTA dopamine neurons for optical stimulation, and recent studies have demonstrated nondopaminergic projection neurons in VTA as well as considerable heterogeneity of the VTA, which can lead to divergent behavioral responses depending on firing parameters and subpopulations of neurons affected (Tsai et al., 2009; Lammel et al., 2011, 2012; Witten et al., 2011; Kim et al., 2012, 2013; Tan et al., 2012; van Zessen et al., 2012; Stamatakis and Stuber, 2012; Chaudhury et al., 2013; Tye et al., 2013).

We next used AAV-CaMKII-ChR2-mCherry and AAVCaMKII-mCherry vectors to express ChR2-mCherry, or mCherry alone as a control, in mPFC, amygdala, or vHippo of D2-GFP mice (Fig. $7 D-F)$. ChR2 and mCherry expression mediated by the
CaMKII-ChR2 virus has previously been demonstrated to colocalize with CaMKII expression, which predominantly labels glutamatergic neurons (Gradinaru et al., 2009; Warden et al., 2012). We activated cells expressing ChR2 in these regions with $20 \mathrm{~Hz}$ blue light for 10 min a day for $5 \mathrm{~d}$, and brains were collected $24 \mathrm{~h}$ after the last stimulation (Fig. $7 A$ ). This stimulation pattern elicited $\sim 27-33 \mathrm{~Hz}$ firing, mainly due to observed doublet spiking. No apparent desensitization of ChR 2 occurred with $5 \mathrm{~d}$ of stimulation; however, we observed a slight increase in firing from 1 to $5 \mathrm{~d}(32-33 \mathrm{~Hz})$ of stimulation. We found that optogenetic activation of $\mathrm{mPFC}$ neurons resulted in $\Delta$ FosB induction in D1-MSNs in NAc core, whereas $\Delta$ FosB induction occurred in both MSN subtypes in NAc shell (Fig. 7D; two-way ANOVA, NAc core: optogenetic stimuli $\times$ cell type $F_{(1,14)}=10.31$, $p<0.05$, Bonferroni post test: $p<0.01$; NAc shell: optogenetic stimuli $F_{(1,14)}=57.17, p<0.001$, Bonferroni post test: $p<0.05$ (D2-MSN), $p<0.01$ (D1-MSN)). No change in $\Delta$ FosB levels was observed in $\mathrm{dStr}$ after $\mathrm{mPFC}$ activation. In contrast, optogenetic activation of amygdala neurons induced $\Delta$ FosB in both MSN subtypes in NAc core, and selectively in D1-MSNs in NAc shell, with no change occurring in dStr (Fig. 7E; two-way ANOVA, NAc core: optogenetic stimuli $F_{(1,10)}=78.92, p<0.0001$, Bonferroni post test: $p<0.001$ (D2-MSN), $p<0.0001$ (D1-MSN); NAc shell: optogenetic stimuli $\times$ cell type: $F_{(1,10)}=30.31, p<0.0001$, Bonferroni post test: $p<0.0001)$. Finally, optogenetic activation of vHippo neurons caused significant $\Delta$ FosB induction only in D1-MSNs in both NAc core and NAc shell, with again no change observed in $\mathrm{d} S \operatorname{tr}$ (Fig. 7F; two-way ANOVA, NAc core: optogenetic stimuli $\times$ cell type $F_{(1,10)}=18.30, p<0.05$, Bonferroni post test: $p<0.01$; NAc shell: optogenetic stimuli $\times$ cell type: $F_{(1,10)}=22.69, p<0.05$, Bonferroni post test: $p<0.01)$.

\section{Discussion}

The present study examines $\Delta$ FosB induction in D1-MSNs and D2-MSNs in striatal regions after several chronic stimuli (Table 1). We first establish the feasibility of using D1-GFP and D2-GFP reporter lines to demonstrate selective $\Delta$ FosB induction in D1MSNs after chronic cocaine and in D2-MSNs after chronic haloperidol. The cocaine findings are consistent with previous studies (Moratalla et al., 1996; Lee et al., 2006) and the established role for $\Delta$ FosB in D1-MSNs in promoting cocaine reward (Kelz et al., 1999; Colby et al., 2003; Grueter et al., 2013). We previously showed that investigator- and self-administered cocaine induces $\Delta$ FosB to an equivalent extent in NAc (Winstanley et al., 2007; Perrotti et al., 2008), and importantly we show here that both modes of cocaine intake induce $\Delta$ FosB selectively in D1-MSNs in all three striatal regions. Our findings are consistent with previous studies demonstrating that acute cocaine induces other immediate early genes and phosphorylation of several intracellular signaling proteins only in D1-MSNs (Bateup et al., 2008; BertranGonzalez et al., 2008). Likewise, the opposite pattern of $\Delta$ FosB induction after chronic haloperidol is consistent with the blockade of this induction by D2-like receptor agonists (Atkins et al., 1999), and with acute haloperidol's selective induction of immediate early genes and phosphorylation of several signaling proteins in D2-MSNs (Bateup et al., 2008; Bertran-Gonzalez et al., 2008).

As with cocaine, we found that chronic exposure to two other drugs of abuse, EtOH and $\Delta(9)$-THC, induces $\Delta$ FosB selectively in D1-MSNs across all striatal regions. We previously demonstrated that EtOH induces $\Delta$ FosB in NAc core, NAc shell, and $\mathrm{d}$ Str, but that $\Delta(9)$-THC significantly upregulates $\Delta$ FosB in NAc core, with a trend seen in the other regions (Perrotti et al., 2008). We similarly observed here the largest $\Delta(9)$-THC induction of 
A

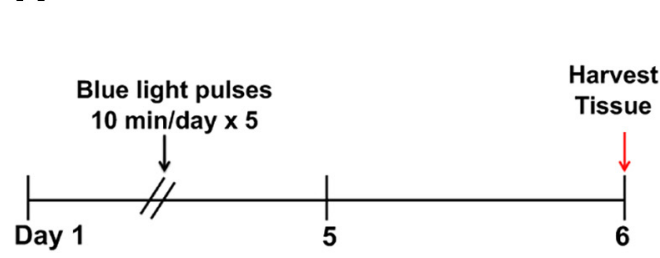

C

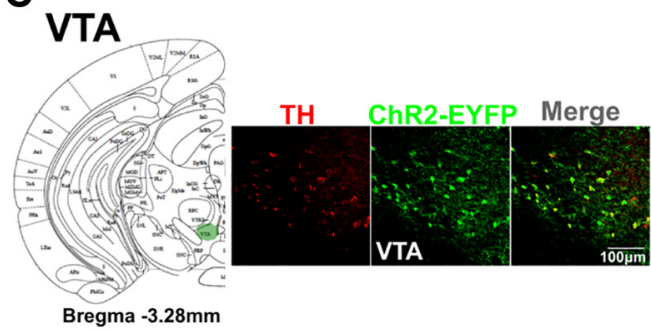

D

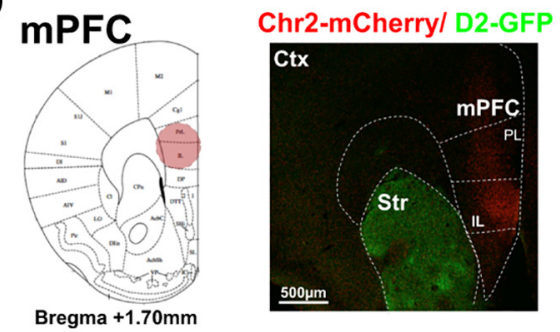

E
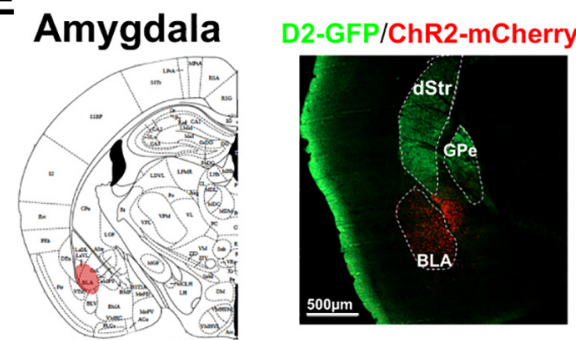

F

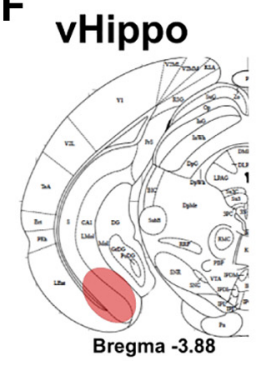

B VTA-hSyn-ChR2
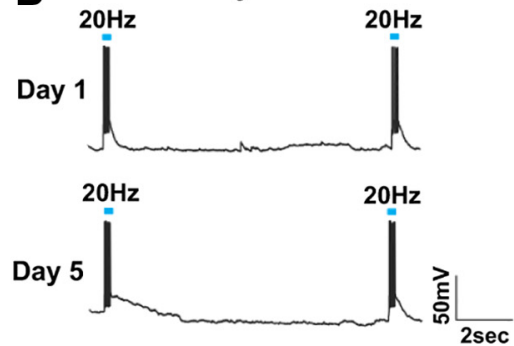

PFC- CAMKII-ChR2

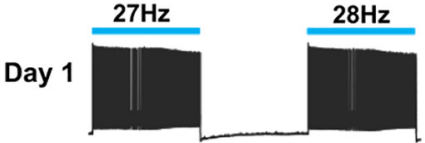

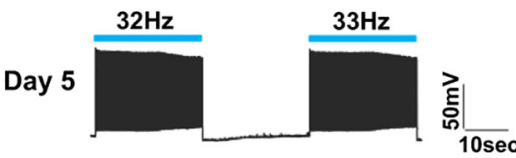

$\square$ AAV-hSyn-EYFP

$\square$ AAV-hSyn-ChR2-EYFP
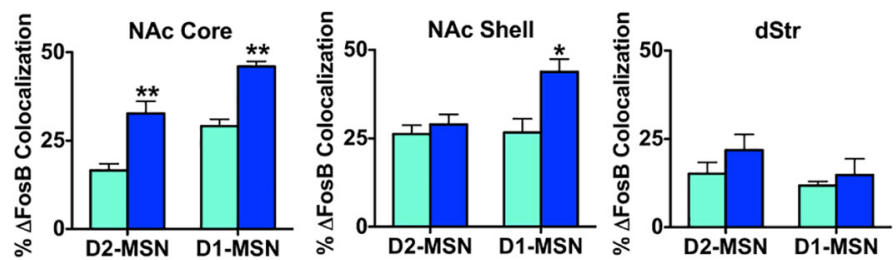

$\square$ AAV-CAMKII-mCherry $\square$ AAV-CAMKII-ChR2-mCherry
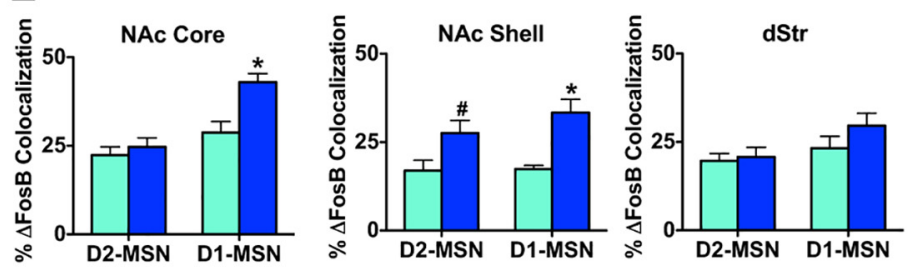
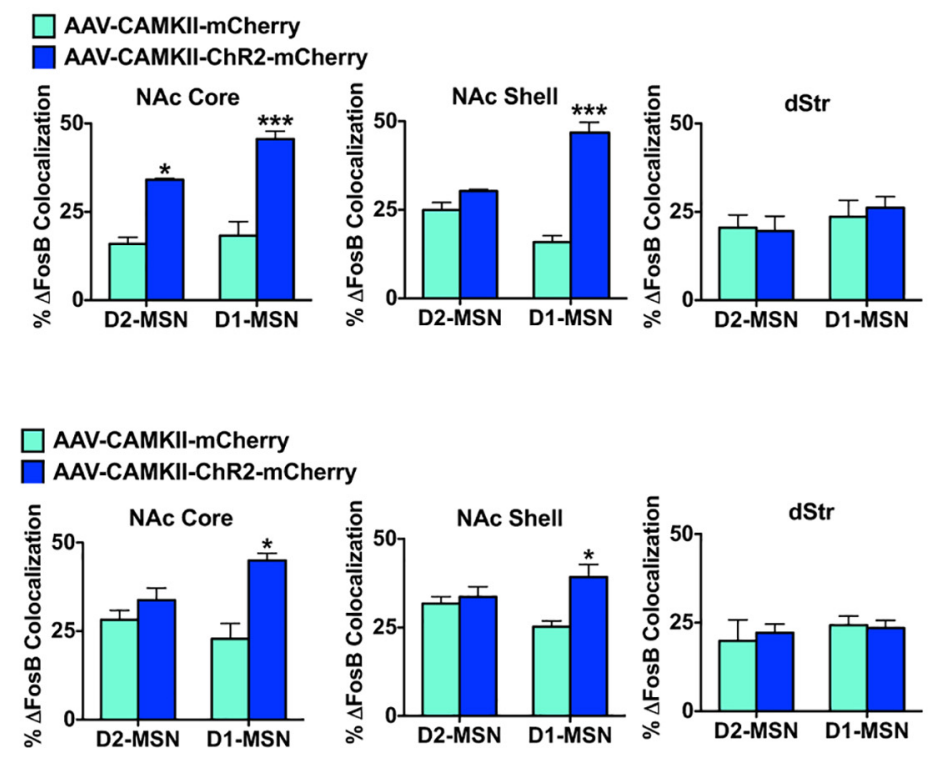

Figure 7. Optogenetic activation of brain regions that innervate the NAc causes distinct patterns of $\triangle$ FosB induction in MSN subtypes and striatal regions. $A$, Optogenetic stimulation paradigm for all conditions. Brains were harvested $24 \mathrm{~h}$ after $5 \mathrm{~d}$ of optogenetic stimulation. $B$, Slice physiology recordings of VTA dopamine neurons expressing AAV-hSyn-ChR2-EYFP or mPFC neurons expressing AAV-hSyn-ChR2-mCherry with $1 \mathrm{~d}$ of stimulation or $5 \mathrm{~d}$ of stimulation. Slices received either phasic $20 \mathrm{~Hz}, 40 \mathrm{~ms}$ blue light ( $473 \mathrm{~nm}$ ) pulses (VTA) or $20 \mathrm{~Hz}$ blue light pulses ( $\mathrm{mPFC}$ ) $\mathbf{C}$, VTA targeting with AAV-hSyn-ChR2-EYFP or AAV-hSyn-EYFP in D2-GFP mice. We observed an overlap in tyrosine hydroxylase (TH, a marker for dopamine neurons) immunolabeling (red) with ChR2-EYFP expressing neurons (green). Scale bar, $100 \mu \mathrm{m}$. Optical stimulation of VTA neurons expressing AAV-hSyn-ChR2-EYFP, for 10 min a day over a $5 \mathrm{~d}$ period with mice examined $24 \mathrm{~h}$ later, caused a significant induction of $\triangle$ FosB in both MSN subtypes in NAc core but only in D1-MSNs in NAc shell. This stimulation parameter caused no induction of $\Delta$ FosB in dStr. Two-way ANOVA, NAc core: optogenetic stimuli $F_{(1,16)}=51.97, p<0.0001$, Bonferroni post test: ${ }^{* *} p<0.001$; (both MSN subtypes) NAc shell: optogenetic stimuli $\times$ cell type: $F_{(1,16)}=13.82, p<0.05$, Bonferroni post test: ${ }^{*} p<0.01$. D, AAV-CaMKII-ChR2-mCherry or AAV-CaMKII-mCherry as a control was expressed in mPFC of D2-GFP mice. Scale bar, $500 \mu \mathrm{m}$. Optical stimulation of mPFC neurons expressing ChR2 for $5 \mathrm{~d}$ with mice examined $24 \mathrm{~h}$ later resulted in $\triangle$ FosB induction in D1-MSNs in NAc core, whereas $\triangle$ FosB induction occurred in both MSN subtypes in NAc shell. No induction was seen in dStr. Two-way ANOVA, NAc core: optogenetic stimuli $\times$ cell type $F_{(1,14)}=10.31, p<0.05$, Bonferroni post test: ${ }^{*} p<0.01$; NAc shell: optogenetic stimuli $F_{(1,14)}=57.17, p<0.001$, Bonferroni post test: ${ }^{\#} p<$ 0.05 (D2-MSN), ${ }^{*} p<0.01$ (D1-MSN). E, AAV-CaMKII-ChR2-mCherry or AAV-CaMKII-mCherry was expressed in amygdala of D2-GFP mice. Scale bar, $500 \mu$ m. (Figure legend continues.) 
Table 1. $\triangle$ FosB induction in striatal MSN subtypes after chronic pharmacological, emotional, and optogenetic stimuli ${ }^{a}$

\begin{tabular}{|c|c|c|c|c|c|c|}
\hline \multirow[b]{2}{*}{ Treatment } & \multicolumn{2}{|l|}{ NAc core } & \multicolumn{2}{|l|}{ NAc shell } & \multicolumn{2}{|l|}{$\mathrm{dStr}$} \\
\hline & D1-MSN & D2-MSN & D1-MSN & D2-MSN & D1-MSN & D2-MSN \\
\hline Cocaine $7 \mathrm{~d}$ (20 mg/kg) & + & - & ++ & - & ++ & - \\
\hline Haloperidol $21 \mathrm{~d}(2 \mathrm{mg} / \mathrm{kg})$ & - & +++ & - & ++++ & - & +++ \\
\hline Morphine 2 pellets over $5 \mathrm{~d}$ ( $25 \mathrm{mg}$ each) & ++ & +++ & ++ & ++++ & ++ & +++ \\
\hline Ethanol $10 \mathrm{~d}$ (10\% two bottle choice) & ++ & - & + & - & + & - \\
\hline$\Delta(9)$-THC $7 \mathrm{~d}$, twice daily (10 mg/kg) & ++ & - & ++ & - & ++ & - \\
\hline Cocaine SA $21 \mathrm{~d}$ (0.5 mg/kg/infusion) & ++ & - & +++ & - & ++ & - \\
\hline Heroin SA $14 \mathrm{~d}$ (30 $\mu \mathrm{g} / \mathrm{kg} /$ infusion) & + & ++ & ++ & +++ & ++ & ++ \\
\hline Juvenile enrichment $28 \mathrm{~d}$ (PND21-PND50) & +++ & +++ & ++ & ++ & ++ & ++ \\
\hline Sucrose $10 \mathrm{~d}$ (10\% two bottle choice) & ++ & ++ & ++ & ++ & ++ & ++ \\
\hline Calorie restriction $10 \mathrm{~d}$ (60\% restriction) & ++ & ++ & ++ & +++ & +++ & ++ \\
\hline Defeat: susceptible $10 \mathrm{~d}$ social defeat stress & - & ++ & - & ++ & - & ++ \\
\hline Defeat: resilient $10 \mathrm{~d}$ social defeat stress & ++ & - & ++ & - & ++ & - \\
\hline Fluoxetine 14 d (20 mg/kg) & ++ & - & ++ & - & ++ & - \\
\hline VTA ChR2 5 d (20 Hz phasic) & ++ & ++ & ++ & - & - & - \\
\hline PFC ChR2 $5 \mathrm{~d}(20 \mathrm{~Hz})$ & ++ & - & ++ & ++ & - & - \\
\hline Amygdala ChR2 $5 \mathrm{~d}(20 \mathrm{~Hz})$ & +++ & +++ & +++++ & - & - & - \\
\hline vHippo ChR2 5 d (20 Hz) & ++ & - & ++ & - & - & - \\
\hline
\end{tabular}

${ }^{a}$ Scale of $\Delta$ FosB fold-induction compared with control conditions:,$+ 1.0-1.5 ;++, 1.5-2.0 ;+++, 2.0-2.5 ;++++, 2.5-3.0 ;+++++, 3.0-3.5$. SA, Self-administration; PND, postnatal day.

$\Delta$ FosB in NAc core in D1-MSNs; our ability to demonstrate induction in other striatal regions is likely due to the cell-specific analysis used. Interestingly, chronic morphine and heroin selfadministration, unlike the other drugs of abuse, induced $\Delta$ FosB in both MSN subtypes to a comparable extent across all striatal regions. A recent study demonstrated that acute morphine induces c-Fos in D1-MSNs, whereas naloxone-precipitated withdrawal after chronic morphine induces c-Fos in D2-MSNs (Enoksson et al., 2012). Although we did not observe signs of opiate withdrawal in our study, it is conceivable that more subtle withdrawal occurring with morphine or heroin administration at the time point studied is responsible for the $\Delta$ FosB induction in D2-MSNs seen here. We showed earlier that $\Delta$ FosB in D1-MSNs, but not D2-MSNs, increases rewarding responses to morphine (Zachariou et al., 2006). It would now be interesting to test the possibility that $\Delta$ FosB induction in D2-MSNs contributes to the aversive effects of opiate withdrawal. Likewise, the potential contribution of drug withdrawal and craving to $\Delta$ FosB induction seen with all drugs should be investigated.

Previous studies demonstrate that environmental enrichment during development induces $\Delta$ FosB in NAc and dStr (Solinas et al., 2009; Lehmann and Herkenham, 2011). Our data demonstrate that this accumulation occurs equally in D1-MSNs and D2-MSNs across all striatal regions. The enrichment paradigm was previously shown to blunt rewarding and locomotor responses to cocaine (Solinas et al., 2009); however, this behavioral phenotype is likely not a consequence of $\Delta$ FosB accumulation because $\Delta$ FosB induction in D1-MSNs alone enhances behav-

$\leftarrow$

(Figure legend continued.) Optical stimulation of amygdala neurons expressing ChR2, for $5 \mathrm{~d}$ with mice examined $24 \mathrm{~h}$ later, induced $\triangle \mathrm{FosB}$ in both MSN subtypes in the NAc core, and in D1-MSNs in NAc shell, but no change occurred in dStr. Two-way ANOVA, NAc core: optogenetic stimuli $F_{(1,10)}=78.92, p<0.0001$, Bonferroni post test: ${ }^{* *} p<0.001$ (D2-MSN), ${ }^{* *} p<$ 0.0001 (D1-MSN); NAc shell: optogenetic stimuli $\times$ cell type: $F_{(1,10)}=30.31, p<0.0001$, Bonferroni post test: ${ }^{* * *} p<0.0001$. $\boldsymbol{F}$, AAV-CaMKII-ChR2-mCherry or AAV-CaMKII-mCherry was expressed in vHippo of D2-GFP mice. Scale bar, $500 \mu \mathrm{m}$. Optical stimulation of vHippo neurons expressing ChR2, for $5 \mathrm{~d}$ with mice examined $24 \mathrm{~h}$ later, caused significant $\Delta$ FosB induction in D1-MSNs in both NAc core and NAc shell, with no change observed in dStr. Two-way ANOVA, NAc core: optogenetic stimuli $\times$ cell type $F_{(1,10)}=18.30, p<0.05$, Bonferroni post test: ${ }^{*} p<0.01$; NAc shell: optogenetic stimuli $\times$ cell type: $F_{(1,10)}=22.69, p<0.05$, Bonferroni post test: ${ }^{*} p<0.01$ ioral responses to cocaine, whereas such induction in D2-MSNs has no discernible effect (Kelz et al., 1999; Colby et al., 2003; Grueter et al., 2013). Chronic sucrose consumption was previously shown to increase $\Delta$ FosB in NAc, and overexpression of $\Delta$ FosB, either in D1-MSNs alone or in both subtypes, in NAc enhances sucrose consumption (Olausson et al., 2006; Wallace et al., 2008). Here, we observed comparable $\Delta$ FosB induction in both MSN subtypes in NAc and dStr after sucrose drinking. Finally, we demonstrated earlier that induction of $\Delta$ FosB in NAc mediates certain adaptive responses to calorie restriction through enhanced motivation for high fat food and reduced energy expenditure (Vialou et al., 2011). Overall, these results demonstrate that $\Delta$ FosB accumulation in NAc and dStr occurs in both D1MSNs and D2-MSNs in response to several natural rewards. This finding is surprising given the observation that $\Delta$ FosB accumulates in D1-MSNs only after another natural reward, chronic wheel running, and that overexpression of $\Delta$ FosB in D1-MSNs enhanced wheel running whereas $\Delta$ FosB overexpression in D2MSNs diminished wheel running (Werme et al., 2002). However, wheel running may activate distinct motor pathways, which are responsible for its different pattern of $\Delta$ FosB induction. In any event, results with the other natural rewards suggest that they differentially control $\Delta$ FosB in striatum compared with more potent drug rewards, such as cocaine, EtOH, and $\Delta(9)$-THC. $\Delta$ FosB induction in both MSN subtypes under these natural rewarding conditions is consistent with a recent study demonstrating that action initiation for a food reward activates both MSN subtypes (Cui et al., 2013).

Chronic social defeat stress induces $\Delta$ FosB in NAc shell of susceptible and resilient mice but in NAc core only in resilient mice (Vialou et al., 2010). Further, $\Delta$ FosB overexpression in D1MSNs promotes resilience after chronic social defeat stress. Chronic treatment with fluoxetine also causes $\Delta$ FosB accumulation in NAc of stress naive mice and in susceptible mice after chronic social defeat stress, and $\Delta$ FosB overexpression was shown to mediate antidepressant-like behavioral responses under the latter conditions (Vialou et al., 2010). Finally, a previous study demonstrated $\Delta$ FosB induction in both MSN subtypes after chronic restraint stress (Perrotti et al., 2004). Results of the present study, where we show $\Delta$ FosB induction selectively in D1MSNs in resilient and fluoxetine-treated mice, but selectively in 
D2-MSNs in susceptible mice, provide important insight into these earlier findings and support the hypothesis that $\Delta$ FosB in D1-MSNs mediates resilience and antidepressant action, whereas $\Delta$ FosB in D2-MSNs might mediate susceptibility. Further work is now needed to test this hypothesis.

Recent work using optogenetics demonstrates the potent role of dopaminergic and glutamatergic afferents to NAc in modulating reward and stress responses (see Results). We make use of these optogenetic tools to examine $\Delta$ FosB induction in D1-MSNs and D2-MSNs after repeated activation of NAc afferent regions. We found that phasic stimulation of VTA neurons, or activation of mainly glutamatergic neurons in amygdala, induces $\Delta$ FosB in D1-MSNs in NAc shell and in both MSN subtypes in NAc core. In contrast, activation of $\mathrm{mPFC}$ neurons results in the opposite pattern of $\Delta$ FosB induction, with increased levels in D1-MSNs in NAc core but induction in both MSN subtypes in NAc shell. Finally, optogenetic activation of vHippo neurons causes $\Delta$ FosB accumulation only in D1-MSNs in NAc core and shell. The vHippo findings are consistent with recent studies demonstrating that hippocampal inputs are much weaker onto D2-MSNs compared with D1-MSNs (MacAskill et al., 2012) and that these inputs control cocaine-induced locomotion (Britt et al., 2012). Moreover, our demonstration of $\Delta$ FosB induction predominantly in D1-MSNs with all inputs is consistent with previous studies showing that $\Delta$ FosB in D1-MSNs enhances rewarding responses to drugs of abuse as well as studies showing that optogenetic stimulation of VTA dopamine neurons or of $\mathrm{mPFC}$, amygdala, or vHippo terminals in NAc promote reward (Kelz et al., 1999; Zachariou et al., 2006; Tsai et al., 2009; Witten et al., 2011; Britt et al., 2012; Grueter et al., 2013).

Finally, it is likely that there are selective neuronal ensembles within these two MSN subtypes that are differentially activated by positive or negative stimuli. This could account for our observation of $\Delta$ FosB induction in D2-MSNs in certain rewarding conditions (opiates and natural rewards) as well as aversive (social defeat) conditions. Striatum is very heterogeneous beyond MSN subtypes, including patch and matrix compartments in both dorsal and ventral striatum (Gerfen, 1992; Watabe-Uchida et al., 2012). Further, previous studies demonstrate activation of a very small percentage of striatal neuronal ensembles by psychostimulants, with enhanced induction of the FosB gene in these activated neurons (Guez-Barber et al., 2011; Liu et al., 2013), although it is unknown whether these activated neurons are D1-MSNs or D2MSNs. The function of $\Delta$ FosB in core versus shell in mediating rewarding and aversive behaviors is likewise unknown. $\Delta$ FosB overexpression in D1-MSNs increased silent synapses in both core and shell, but expression in D2-MSNs decreased silent synapses in shell only (Grueter et al., 2013). Further, $\Delta$ FosB induction in core versus shell is likely mediated through different mechanisms, as we found cocaine-mediated CaMKII $\alpha$ stabilization of $\Delta \mathrm{FosB}$ in shell but not core leading to greater $\Delta \mathrm{FosB}$ accumulation in shell (Robison et al., 2013). Future studies that selectively target MSN subtypes in core versus shell, activated neuronal ensembles, or patch versus matrix compartments will help define the behavioral role of $\Delta$ FosB within these heterogeneous regions.

Overall, these circuit-mediated cell type-selective induction patterns of $\Delta$ FosB in NAc suggest that rewarding and stressful stimuli differentially engage distinct NAc afferents to encode specific features of these stimuli. Our results not only provide comprehensive insight into the induction of $\Delta$ FosB in striatal MSN subtypes by chronic stimuli but also illustrate the utility in using
$\Delta$ FosB as a molecular marker to understand the lasting effects of specific neural circuits in influencing NAc function.

\section{References}

Adamantidis AR, Tsai HC, Boutrel B, Zhang F, Stuber GD, Budygin EA, Touriño C, Bonci A, Deisseroth K, de Lecea L (2011) Optogenetic interrogation of dopaminergic modulation of the multiple phases of rewardseeking behavior. J Neurosci 31:10829-10835. CrossRef Medline

Albin RL, Young AB, Penney JB (1989) The functional anatomy of basal ganglia disorders. Trends Neurosci 12:366-375. CrossRef Medline

Atkins JB, Chlan-Fourney J, Nye HE, Hiroi N, Carlezon WA Jr, Nestler EJ (1999) Region-specific induction of $\delta$ FosB by repeated administration of typical versus atypical antipsychotic drugs. Synapse 33:118-128. CrossRef Medline

Bateup HS, Svenningsson P, Kuroiwa M, Gong S, Nishi A, Heintz N, Greengard P (2008) Cell type-specific regulation of DARPP-32 phosphorylation by psychostimulant and antipsychotic drugs. Nat Neurosci 11:932-939. CrossRef Medline

Berton O, McClung CA, Dileone RJ, Krishnan V, Renthal W, Russo SJ, Graham D, Tsankova NM, Bolanos CA, Rios M, Monteggia LM, Self DW, Nestler EJ (2006) Essential role of BDNF in the mesolimbic dopamine pathway in social defeat stress. Science 311:864-868. CrossRef Medline

Bertran-Gonzalez J, Bosch C, Maroteaux M, Matamales M, Hervé D, Valjent E, Girault JA (2008) Opposing patterns of signaling activation in dopamine D1 and D2 receptor-expressing striatal neurons in response to cocaine and haloperidol. J Neurosci 28:5671-5685. CrossRef Medline

Britt JP, Benaliouad F, McDevitt RA, Stuber GD, Wise RA, Bonci A (2012) Synaptic and behavioral profile of multiple glutamatergic inputs to the nucleus accumbens. Neuron 76:790-803. CrossRef Medline

Chan CS, Peterson JD, Gertler TS, Glajch KE, Quintana RE, Cui Q, Sebel LE, Plotkin JK, Heiman M, Heintz N, Greengard P, Surmeier DJ (2012) Strain-specific regulation of striatal phenotype in Drd2-eGFP BAC transgenic mice. J Neurosci 32:9124-9132. CrossRef Medline

Chaudhury D, Walsh JJ, Friedman AK, Juarez B, Ku SM, Koo JW, Ferguson D, Tsai HC, Pomeranz L, Christoffel DJ, Nectow AR, Ekstrand M, Domingos A, Mazei-Robison MS, Mouzon E, Lobo MK, Neve RL, Friedman JM, Russo SJ, Deisseroth K, et al. (2013) Rapid regulation of depressionrelated behaviours by control of midbrain dopamine neurons. Nature 493:532-536. CrossRef Medline

Colby CR, Whisler K, Steffen C, Nestler EJ, Self DW (2003) $\Delta$ FosB enhances incentive for cocaine. J Neurosci 23:2488-2493. Medline

Covington HE 3rd, Lobo MK, Maze I, Vialou V, Hyman JM, Zaman S, LaPlant Q, Mouzon E, Ghose S, Tamminga CA, Neve RL, Deisseroth K, Nestler EJ (2010) Antidepressant effect of optogenetic stimulation of the medial prefrontal cortex. J Neurosci 30:16082-16090. CrossRef Medline

Cui G, Jun SB, Jin X, Pham MD, Vogel SS, Lovinger DM, Costa RM (2013) Concurrent activation of striatal direct and indirect pathways during action initiation. Nature 494:238-242. CrossRef Medline

Enoksson T, Bertran-Gonzalez J, Christie MJ (2012) Nucleus accumbens D2- and D1-receptor expressing medium spiny neurons are selectively activated by morphine withdrawal and acute morphine, respectively. Neuropharmacology 62:2463-2471. CrossRef Medline

Gerfen CR (1992) The neostriatal mosaic: multiple levels of compartmental organization in the basal ganglia. Annu Rev Neurosci 15:285-320. CrossRef Medline

Gittis AH, Kreitzer AC (2012) Striatal microcircuitry and movement disorders. Trends Neurosci 35:557-564. CrossRef Medline

Gong S, Zheng C, Doughty ML, Losos K, Didkovsky N, Schambra UB, Nowak NJ, Joyner A, Leblanc G, Hatten ME, Heintz N (2003) A gene expression atlas of the central nervous system based on bacterial artificial chromosomes. Nature 425:917-925. CrossRef Medline

Gradinaru V, Mogri M, Thompson KR, Henderson JM, Deisseroth K (2009) Optical deconstruction of parkinsonian neural circuitry. Science 324: 354-359. CrossRef Medline

Gradinaru V, Zhang F, Ramakrishnan C, Mattis J, Prakash R, Diester I, Goshen I, Thompson KR, Deisseroth K (2010) Molecular and cellular approaches for diversifying and extending optogenetics. Cell 141:154-165. CrossRef Medline

Graybiel AM (2000) The basal ganglia. Curr Biol 10:R509-R511. CrossRef Medline

Green TA, Alibhai IN, Roybal CN, Winstanley CA, Theobald DE, Birnbaum SG, Graham AR, Unterberg S, Graham DL, Vialou V, Bass CE, Terwilliger 
EF, Bardo MT, Nestler EJ (2010) Environmental enrichment produces a behavioral phenotype mediated by low cyclic adenosine monophosphate response element binding (CREB) activity in the nucleus accumbens. Biol Psychiatry 67:28-35. CrossRef Medline

Grueter BA, Robison AJ, Neve RL, Nestler EJ, Malenka RC (2013) $\Delta$ FosB differentially modulates nucleus accumbens direct and indirect pathway function. Proc Natl Acad Sci U S A 110:1923-1928. CrossRef Medline

Guez-Barber D, Fanous S, Golden SA, Schrama R, Koya E, Stern AL, Bossert JM, Harvey BK, Picciotto MR, Hope BT (2011) FACS identifies unique cocaine-induced gene regulation in selectively activated adult striatal neurons. J Neurosci 31:4251-4259. CrossRef Medline

Heiman M, Schaefer A, Gong S, Peterson JD, Day M, Ramsey KE, SuárezFarinas M, Schwarz C, Stephan DA, Surmeier DJ, Greengard P, Heintz N (2008) A translational profiling approach for the molecular characterization of CNS cell types. Cell 135:738-748. CrossRef Medline

Hiroi N, Graybiel AM (1996) Atypical and typical neuroleptic treatments induce distinct programs of transcription factor expression in the striatum. J Comp Neurol 374:70-83. CrossRef Medline

Hiroi N, Brown JR, Haile CN, Ye H, Greenberg ME, Nestler EJ (1997) FosB mutant mice: Loss of chronic cocaine induction of Fos-related proteins and heightened sensitivity to cocaine's psychomotor and rewarding effects. Proc Natl Acad Sci U S A 94:10397-10402. CrossRef Medline

Hope BT, Nye HE, Kelz MB, Self DW, Iadarola MJ, Nakabeppu Y, Duman RS, Nestler EJ (1994) Induction of a long-lasting AP-1 complex composed of altered fos-like proteins in brain by chronic cocaine and other chronic treatments. Neuron 13:1235-1244. CrossRef Medline

Kalivas PW, Churchill L, Klitenick MA (1993) GABA and enkephalin projection from the nucleus accumbens and ventral pallidum to the ventral tegmental area. Neuroscience 57:1047-1060. CrossRef Medline

Kaplan GB, Leite-Morris KA, Fan W, Young AJ, Guy MD (2011) Opiate sensitization induces FosB $/ \Delta$ FosB expression in prefrontal cortical, striatal and amygdala brain regions. PLoS One 6:e23574. CrossRef Medline

Kelz MB, Chen J, Carlezon WA Jr, Whisler K, Gilden L, Beckmann AM, Steffen C, Zhang YJ, Marotti L, Self DW, Tkatch T, Baranauskas G, Surmeier DJ, Neve RL, Duman RS, Picciotto MR, Nestler EJ (1999) Expression of the transcription factor $\triangle$ FosB in the brain controls sensitivity to cocaine. Nature 401:272-276. CrossRef Medline

Kim KM, Baratta MV, Yang A, Lee D, Boyden ES, Fiorillo CD (2012) Optogenetic mimicry of the transient activation of dopamine neurons by natural reward is sufficient for operant reinforcement. PLoS One 7:e33612. CrossRef Medline

Kim TI, McCall JG, Jung YH, Huang X, Siuda ER, Li Y, Song J, Song YM, Pao HA, Kim RH, Lu C, Lee SD, Song IS, Shin G, Al-Hasani R, Kim S, Tan MP, Huang Y, Omenetto FG, Rogers JA, et al. (2013) Injectable, cellularscale optoelectronics with applications for wireless optogenetics. Science 340:211-216. CrossRef Medline

Koo JW, Mazei-Robison MS, Chaudhury D, Juarez B, LaPlant Q, Ferguson D, Feng J, Sun H, Scobie KN, Damez-Werno D, Crumiller M, Ohnishi YN, Ohnishi YH, Mouzon E, Dietz DM, Lobo MK, Neve RL, Russo SJ, Han $\mathrm{MH}$, Nestler EJ (2012) BDNF is a negative modulator of morphine action. Science 338:124-128. CrossRef Medline

Krishnan V, Han MH, Graham DL, Berton O, Renthal W, Russo SJ, Laplant Q, Graham A, Lutter M, Lagace DC, Ghose S, Reister R, Tannous P, Green TA, Neve RL, Chakravarty S, Kumar A, Eisch AJ, Self DW, Lee FS, et al. (2007) Molecular adaptations underlying susceptibility and resistance to social defeat in brain reward regions. Cell 131:391-404. CrossRef Medline

Kumar S, Black SJ, Hultman R, Szabo ST, DeMaio KD, Du J, Katz BM, Feng G, Covington HE 3rd, Dzirasa K (2013) Cortical control of affective networks. J Neurosci 33:1116-1129. CrossRef Medline

Lammel S, Ion DI, Roeper J, Malenka RC (2011) Projection-specific modulation of dopamine neuron synapses by aversive and rewarding stimuli. Neuron 70:855-862. CrossRef Medline

Lammel S, Lim BK, Ran C, Huang KW, Betley MJ, Tye KM, Deisseroth K, Malenka RC (2012) Input-specific control of reward and aversion in the ventral tegmental area. Nature 491:212-217. CrossRef Medline

Larson EB, Akkentli F, Edwards S, Graham DL, Simmons DL, Alibhai IN, Nestler EJ, Self DW (2010) Striatal regulation of $\Delta$ FosB, FosB, and cFos during cocaine self-administration and withdrawal. J Neurochem 115: 112-122. CrossRef Medline

Lee KW, Kim Y, Kim AM, Helmin K, Nairn AC, Greengard P (2006) Cocaine-induced dendritic spine formation in D1 and D2 dopamine receptor-containing medium spiny neurons in nucleus accumbens. Proc Natl Acad Sci U S A 103:3399-3404. CrossRef Medline

Lehmann ML, Herkenham M (2011) Environmental enrichment confers stress resiliency to social defeat through an infralimbic cortex-dependent neuroanatomical pathway. J Neurosci 31:6159-6173. CrossRef Medline

Liu QR, Rubio FJ, Bossert JM, Marchant NJ, Fanous S, Hou X, Shaham Y, Hope BT (2013) Detection of molecular alterations in methamphetamineactivated Fos-expressing neurons from a single rat dorsal striatum using fluorescence-activated cell sorting (FACS). J Neurochem. Advance online publication. Retrieved July 29, 2013. doi: 10.1111/jnc.12381. CrossRef Medline

Lobo MK, Covington HE 3rd, Chaudhury D, Friedman AK, Sun H, DamezWerno D, Dietz DM, Zaman S, Koo JW, Kennedy PJ, Mouzon E, Mogri M, Neve RL, Deisseroth K, Han MH, Nestler EJ (2010) Cell type-specific loss of BDNF signaling mimics optogenetic control of cocaine reward. Science 330:385-390. CrossRef Medline

Lobo MK, Nestler EJ (2011) The striatal balancing act in drug addiction: distinct roles of direct and indirect pathway medium spiny neurons. Front Neuroanat 5:41. CrossRef Medline

Lobo MK, Karsten SL, Gray M, Geschwind DH, Yang XW (2006) FACSarray profiling of striatal projection neuron subtypes in juvenile and adult mouse brains. Nat Neurosci 9:443-452. CrossRef Medline

MacAskill AF, Little JP, Cassel JM, Carter AG (2012) Subcellular connectivity underlies pathway-specific signaling in the nucleus accumbens. Nat Neurosci 15:1624-1626. CrossRef Medline

Maze I, Covington HE 3rd, Dietz DM, LaPlant Q, Renthal W, Russo SJ, Mechanic M, Mouzon E, Neve RL, Haggarty SJ, Ren Y, Sampath SC, Hurd YL, Greengard P, Tarakhovsky A, Schaefer A, Nestler EJ (2010) Essential role of the histone methyltransferase G9a in cocaine-induced plasticity. Science 327:213-216. CrossRef Medline

Mazei-Robison MS, Koo JW, Friedman AK, Lansink CS, Robison AJ, Vinish M, Krishnan V, Kim S, Siuta MA, Galli A, Niswender KD, Appasani R, Horvath MC, Neve RL, Worley PF, Snyder SH, Hurd YL, Cheer JF, Han MH, Russo SJ, et al. (2011) Role for mTOR signaling and neuronal activity in morphine-induced adaptations in ventral tegmental area dopamine neurons. Neuron 72:977-990. CrossRef Medline

McClung CA, Nestler EJ (2003) Regulation of gene expression and cocaine reward by CREB and $\triangle$ FosB. Nat Neurosci 6:1208-1215. CrossRef Medline

McDaid J, Graham MP, Napier TC (2006) Methamphetamine-induced sensitization differentially alters pCREB and $\triangle$ FosB throughout the limbic circuit of the mammalian brain. Mol Pharmacol 70:2064-2074. CrossRef Medline

Moratalla R, Vallejo M, Elibol B, Graybiel AM (1996) D1-class dopamine receptors influence cocaine-induced persistent expression of fos-related proteins in striatum. Neuroreport 8:1-5. CrossRef Medline

Muller DL, Unterwald EM (2005) D1 dopamine receptors modulate $\delta$ FosB induction in rat striatum after intermittent morphine administration. J Pharmacol Exp Ther 314:148-154. CrossRef Medline

Narayan S, Kass KE, Thomas EA (2007) Chronic haloperidol treatment results in a decrease in the expression of myelin/oligodendrocyte-related genes in the mouse brain. J Neurosci Res 85:757-765. CrossRef Medline

Navarro M, Carrera MR, Fratta W, Valverde O, Cossu G, Fattore L, Chowen JA, Gomez R, del Arco I, Villanua MA, Maldonado R, Koob GF, Rodriguez de Fonseca F (2001) Functional interaction between opioid and cannabinoid receptors in drug self-administration. J Neurosci 21:53445350. Medline

Nelson AB, Hang GB, Grueter BA, Pascoli V, Luscher C, Malenka RC, Kreitzer AC (2012) A comparison of striatal-dependent behaviors in wildtype and hemizygous Drd1a and Drd2 BAC transgenic mice. J Neurosci 32:9119-9123. CrossRef Medline

Nicola SM (2007) The nucleus accumbens as part of a basal ganglia action selection circuit. Psychopharmacology 191:521-550. CrossRef Medline

Olausson P, Jentsch JD, Tronson N, Neve RL, Nestler EJ, Taylor JR (2006) $\triangle \mathrm{FosB}$ in the nucleus accumbens regulates food-reinforced instrumental behavior and motivation. J Neurosci 26:9196-9204. CrossRef Medline

Perrotti LI, Hadeishi Y, Ulery PG, Barrot M, Monteggia L, Duman RS, Nestler EJ (2004) Induction of $\delta$ FosB in reward-related brain structures after chronic stress. J Neurosci 24:10594-10602. CrossRef Medline

Perrotti LI, Weaver RR, Robison B, Renthal W, Maze I, Yazdani S, Elmore RG, Knapp DJ, Selley DE, Martin BR, Sim-Selley L, Bachtell RK, Self DW, 
Nestler EJ (2008) Distinct patterns of DeltaFosB induction in brain by drugs of abuse. Synapse 62:358-369. CrossRef Medline

Renthal W, Carle TL, Maze I, Covington HE 3rd, Truong HT, Alibhai I, Kumar A, Montgomery RL, Olson EN, Nestler EJ (2008) $\Delta$ FosB mediates epigenetic desensitization of the c-fos gene after chronic amphetamine exposure. J Neurosci 28:7344-7349. CrossRef Medline

Renthal W, Kumar A, Xiao G, Wilkinson M, Covington HE 3rd, Maze I, Sikder D, Robison AJ, LaPlant Q, Dietz DM, Russo SJ, Vialou V, Chakravarty S, Kodadek TJ, Stack A, Kabbaj M, Nestler EJ (2009) Genome wide analysis of chromatin regulation by cocaine reveals a novel role for sirtuins. Neuron 62:335-348. CrossRef Medline

Robison AJ, Nestler EJ (2011) Transcriptional and epigenetic mechanisms of addiction. Nat Rev Neurosci 12:623-637. CrossRef Medline

Robison AJ, Vialou V, Mazei-Robison M, Feng J, Kourrich S, Collins M, Wee S, Koob G, Turecki G, Neve R, Thomas M, Nestler EJ (2013) Behavioral and structural responses to chronic cocaine require a feedforward loop involving $\Delta$ FosB and calcium/calmodulin-dependent protein kinase II in the nucleus accumbens shell. J Neurosci 33:4295-4307. CrossRef Medline

Smith RJ, Lobo MK, Spencer S, Kalivas PW (2013) Cocaine-induced adaptations in D1 and D2 accumbens projection neurons (a dichotomy not necessarily synonymous with direct and indirect pathways). Curr Opin Neurobiol 23:546-552. CrossRef Medline

Solinas M, Thiriet N, El Rawas R, Lardeux V, Jaber M (2009) Environmental enrichment during early stages of life reduces the behavioral, neurochemical, and molecular effects of cocaine. Neuropsychopharmacology 34: 1102-1111. CrossRef Medline

Sparta DR, Stamatakis AM, Phillips JL, Hovelsø N, van Zessen R, Stuber GD (2012) Construction of implantable optical fibers for long-term optogenetic manipulation of neural circuits. Nat Protoc 7:12-23. CrossRef Medline

Stamatakis AM, Stuber GD (2012) Activation of lateral habenula inputs to the ventral midbrain promotes behavioral avoidance. Nat Neurosci 24: 1105-1107. CrossRef Medline

Stuber GD, Britt JP, Bonci A (2012) Optogenetic modulation of neural circuits that underlie reward seeking. Biol Psychiatry 71:1061-1067. CrossRef Medline

Tan KR, Yvon C, Turiault M, Mirzabekov JJ, Doehner J, Labouèbe G, Deisseroth K, Tye KM, Lüscher C (2012) GABA neurons of the VTA drive conditioned place aversion. Neuron 73:1173-1183. CrossRef Medline

Teegarden SL, Bale TL (2007) Decreases in dietary preference produce increased emotionality and risk for dietary relapse. Biol Psychiatry 61:10211029. CrossRef Medline

Tsai HC, Zhang F, Adamantidis A, Stuber GD, Bonci A, de Lecea L, Deisseroth $\mathrm{K}$ (2009) Phasic firing in dopaminergic neurons is sufficient for behavioral conditioning. Science 324:1080-1084. CrossRef Medline

Tye KM, Mirzabekov JJ, Warden MR, Ferenczi EA, Tsai HC, Finkelstein J, Kim SY, Adhikari A, Thompson KR, Andalman AS, Gunaydin LA, Witten IB, Deisseroth K (2013) Dopamine neurons modulate neural encoding and expression of depression-related behaviour. Nature 493:537-541. CrossRef Medline

van Zessen R, Phillips JL, Budygin EA, Stuber GD (2012) Activation of VTA GABA neurons disrupts reward consumption. Neuron 73:1184-1194. CrossRef Medline

Vialou V, Robison AJ, Laplant QC, Covington HE 3rd, Dietz DM, Ohnishi YN, Mouzon E, Rush AJ 3rd, Watts EL, Wallace DL, Iñiguez SD, Ohnishi YH, Steiner MA, Warren BL, Krishnan V, Bolaños CA, Neve RL, Ghose S, Berton O, Tamminga CA, et al. (2010) $\Delta$ FosB in brain reward circuits mediates resilience to stress and antidepressant responses. Nat Neurosci 13:745-752. CrossRef Medline

Vialou V, Cui H, Perello M, Mahgoub M, Yu HG, Rush AJ, Pranav H, Jung S, Yangisawa M, Zigman JM, Elmquist JK, Nestler EJ, Lutter M (2011) A role for $\Delta$ FosB in calorie restriction-induced metabolic changes. Biol Psychiatry 70:204-207. CrossRef Medline

Wallace DL, Vialou V, Rios L, Carle-Florence TL, Chakravarty S, Kumar A, Graham DL, Green TA, Kirk A, Iñiguez SD, Perrotti LI, Barrot M, DiLeone RJ, Nestler EJ, Bolaños-Guzmán CA (2008) The influence of DeltaFosB in the nucleus accumbens on natural reward-related behavior. J Neurosci 28:10272-10277. CrossRef Medline

Warden MR, Selimbeyoglu A, Mirzabekov JJ, Lo M, Thompson KR, Kim SY, Adhikari A, Tye KM, Frank LM, Deisseroth K (2012) A prefrontal cortex-brainstem neuronal projection that controls response to behavioural challenge. Nature 492:428-432. CrossRef Medline

Watabe-Uchida M, Zhu L, Ogawa SK, Vamanrao A, Uchida N (2012) Whole-brain mapping of direct inputs to midbrain dopamine neurons. Neuron 74:858-873. CrossRef Medline

Werme M, Messer C, Olson L, Gilden L, Thorén P, Nestler EJ, Brené S (2002) $\Delta$ FosB regulates wheel running. J Neurosci 22:8133-8138. Medline

Winstanley CA, LaPlant Q, Theobald DE, Green TA, Bachtell RK, Perrotti LI, DiLeone RJ, Russo SJ, Garth WJ, Self DW, Nestler EJ (2007) $\Delta$ FosB induction in orbitofrontal cortex mediates tolerence to cocaine-induced cognitive dysfunction. J Neurosci 27:10497-10507. CrossRef Medline

Witten IB, Steinberg EE, Lee SY, Davidson TJ, Zalocusky KA, Brodsky M, Yizhar O, Cho SL, Gong S, Ramakrishnan C, Stuber GD, Tye KM, Janak PH, Deisseroth K (2011) Recombinase-driver rat lines: tools, techniques, and optogenetic application to dopamine-mediated reinforcement. Neuron 72:721-733. CrossRef Medline

Yizhar O, Fenno LE, Davidson TJ, Mogri M, Deisseroth K (2011) Optogenetics in neural systems. Neuron 71:9-34. CrossRef Medline

Yoneyama N, Crabbe JC, Ford MM, Murillo A, Finn DA (2008) Voluntary ethanol consumption in 22 inbred mouse strains. Alcohol 42:149-160. CrossRef Medline

Zachariou V, Bolanos CA, Selley DE, Theobald D, Cassidy MP, Kelz MB, Shaw-Lutchman T, Berton O, Sim-Selley LJ, Dileone RJ, Kumar A, Nestler EJ (2006) An essential role for DeltaFosB in the nucleus accumbens in morphine action. Nat Neurosci 9:205-211. CrossRef Medline 